$\frac{3}{3}$

$\frac{1}{5}$

3

8

ल

ई

$+y^{3}$

5

5

5
+3
3
3
3

$-3$

रे

.

.

5

8

2
-2
+

so

2

$\varepsilon$

f

\title{
$\frac{\sqrt{2}}{2}$
}

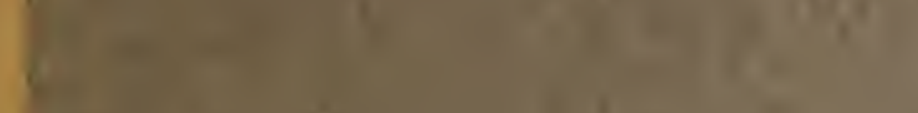

$1+$

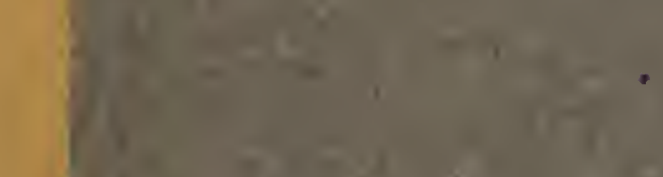

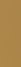

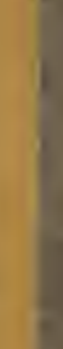

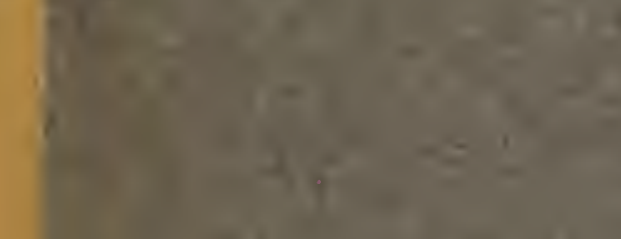


$A-W$ ceeds

HARVARD UNIVERSITY.

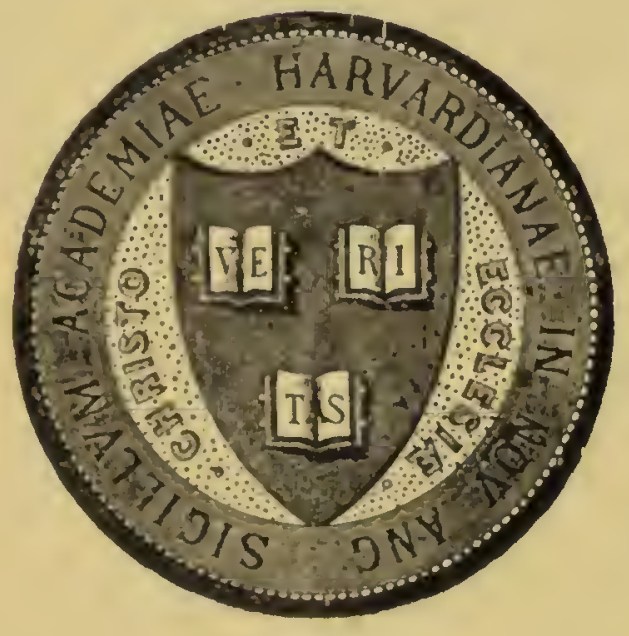

LIBRARY

of THr.

MUSEUM OF COMPARATIVE ZOÖLOGY 51,348

GIFT OF

Samuel Henshaw.

February 1, 1919. 
New Hampshire College Agricultural Experiment Station TECHNICAL BULLETIN NO. 5

\title{
A PARTIAL BIBLIOGRAPHY
}

OF THE

\section{ECONOMIC RELATIONS}

OF

\section{North American Birds}

HY

\author{
CLARENCE M. WEED
}

\section{DURHAM}

NEW HAMPSHIRE COLLEGE

OF AGRICULTURE AND THE MECHANIC ARTS 


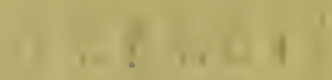

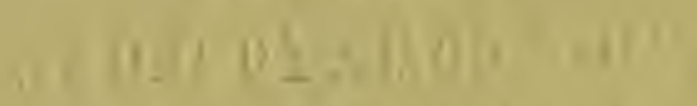

Iy, ingu| |xis 
New Hampshire College Agricultural Experiment Station TECHNICAL BULLETIN NO. 5

A PARTIAL BIBLIOGRAPHY

OF THE

\section{ECONOMIC RELATIONS}

OF

\section{North American Birds}

BY

CLARENCE M. WEED

DURHAM

NEW HAMPSHIRE COLLEGE

OF AGRICULTURE AND 'THE MECHANIC ARTS

1902 


\title{
AGRICOLTORAL EXPERIMENT STATION
}

\author{
DURHAM, N. H.
}

\section{BOARD OF CONTROL}

How. JOHN G. TALI,ANT, Chairman, P'embroke.

HoN. GEORGE A. WASON, New Boston.

CHARLES W. STONE, A. M., Secretary, Andover. Pres. CHARLES S. MURKLAND, ex-officio, Durham.

\section{THE STATION COUNCIL}

FRED W. MORSE, M. S., Vice-Director and Chemist. CHARLES H. PETTEE, A. M., C. E., Meteorologist. HERBERT H. LAMSON, M. D., Bacteriologist.

CLARENCE M. IVEED, D. Sc., Entomologist. FRANK WM. RANE, B. AGR., M. S., Horticulturist. HARRY HAYWARD, M. S., Agrriculturist.

\section{ASSISTANTS}

HARRY F. HALL. Assistant Horticulturist. ALBERT F. CONRADI, M. S., Assistant Entomologist. LUCIAN A. HILL, A. B., Assistant Chemist. ARThUR L. SULLIVAN, B. S., Assistant Chemist. FREDERICK C. KEITH, Clerk. 


\title{
A PARTIAL BIBLIOGRAPHY OF THE ECONOMIC RELATIONS OF NORTH AMERICAN BIRDS
}

\author{
lil ('LALENCL M. Wlit)
}

'The importance of birds as checks mpon the mudue increase of noxions insects has long been recognized by observing men scattered here and there thronghont the Inited States. Bnt a general appreciation of the value of these feathered allies is of comparatively recent derelopment, and in some regions they are still mappreciated.

'The literature which has led to a wider knowledge of the value of birds has been scattered throngh many publications, much of which is inaccessible to the general reader, and some of it difticult to obtain eren by the specialist. In the following pages I have attempted to bring together a bibliographic list of the more important articles treating of the economic relations of our birds. In compiling it I have had the help of Messi's. A. F. Comradi, W. F. Fiske, and R. A. Cushman, while assistants in the entomological department of this station. For a number of citations of articles in Forest and Stream I am indebted to the pages of The Auk, while a few others have been gleaned from various other sources. It has been impracticable to include citations of the great mass of literatnre treating specifically of game birds, or their acclimation and domestication, as well as of the thonsands of references to the English sparrow, and of the many general bird books of recent year's.

1808-14. Whosox, Alexaxder. American Ornithology; or, the Natural History of the Birds of the L'nited States: Illustrated with plates engraved and colored from original drawings taken from nature. By. Alexander Wilson. v. I-IX Philadelphia; Published by Bradford \& Inskeep.

Much information as to feeding habits. 
1825-33. Bonaparte, Charles Luchex. American Ornithology; or, the Natural History of the Birds inhabiting the United States of America, not given by Wilson, with figures drawn, engraved, and colored, from nature. By Charles Lucien Bonaparte. v. I (IV). Philadelphia: Carey, Lea \& Cary, Chestnut street. London: John Miller, 40 Pall Mall.

1831-39. Aunurox, Jonx Janes. Ornithological Biograplyy, or an acconnt of the habits of the Birds of the United States of America ; accompanied by descriptions of the objects represented in the work entitled "The Birds of Anerica," and interspersed with delineations of Aneri(“an scenery and manners. By .John James Audubon. F. R. S. S. L. \& E. Edinburg: Adam Black.

Frequent references to feelingr habits.

1832-84. Nurmal, 'Thomas. A Mantual of the Ornithology of the United States and of Camada. By 'Thomas Nuttall, A. M., F. I. S. (r. I) The Land Birds. Cambridge: Hilliard and Brown, booksellers to the University. MIJCCCXXXII. (v. II) 'The Water Birds. Boston: Hilliarl, Gray \& Co. MI)CCCXXXIV.

Many references to insect and other food of birds.

1840-44. Armunx. J. I. The Birds of America, from drawings mate in the Enited States and their Territories. By Johm dames Auduhon. Philadelphia: J. B3. Chevalier. $1840-44.7$ rols.

1850. Kuntexis, J. P. Fragments of Natural History. Family Visitor (weekly newspaper), V. I, No. 1, 1850, p. 1.

Notes on twenty-one species, chicfly regarding their relative abundance compared with former years. Washington eagle, red-tailed, red-shouldered, broad-winged, Cooper's and swallow-tailed hawks, groosander, mallard, summer duck, wild turkey, partridge, quail, pileated woolcock, turkey buzzard, raven, crow, crow blackbird, robin, bluebird, thrush, catbirr.

1850. Knatraxn, .J. P. Editorial Correspondence. Family Visitor, Y. I, No. 10, 1850, 1). 72. 
1850. (Kentaxi, J. P'.) 'The W'ild l'igeon. Family Visitol', v. I, No. 17, 1850, p. 19:3.

1852. (Rx.11, M. C., Elitor.) 'The Cow Blackbirl. Family risitor, r. III, No. 9, 1852, p. 68.

1854. (folkis, Jonx. Importation of Skylarks. U. S. Patent ()flice, Agricultural Report, 1853 , pp. 70-71.

Account of an importation of skylarks into America in the spring of 1853.

1S54. Worrori), H. L. On the Importation and Protection of Useful Birds. U. S. Patent Onice, Agricultural Report, 1853 .

A strong recommendation for the importation of immensc numbers of European song and insectivorous birds into America.

1855. Brows, D. J. Climatology. U. S. Patent Office, Agricultural Report, 1854, pp. 436-441.

Dates of first appearance of barn-swallow and whippoorwill in various towns of the United States in spring of 185.1.

1859. Kurkptrick, John: Rapacions Birds of Ohio. Ohio Agricultural Report for 1858, pp. 341-383.

1860. KmR patrick, Jomn. Birds of Ohio. Ohio Fammer (newspaper, Cleveland), 1858-60.

A series of articles running through three years.

1861. Collins, W. O. Report of Senate Select Committee, upon Senate Bill No. 12, "For the Protection of Birds and Game." Fifteenth Aunual Report Ohio State Board of Agriculture for 1860 (1861), pp. 381-390.

Facts in the natural history of Ohio birds, with recommendations for legislative action.

1861. (Harris, S. D., Editor.) Field Notes, I, 1861, p. 6..

Notc on the introduction of the English skylark, at Columbus, in 1851.

1861. Welds, D. A. On the Feeding and Frowth of the American Robin. U. S. Patent Oflice, Report on Agriculture, 1860, pl. 88-89. 
Abstract of an article by Professor Treadwell of Cambridge, Mass, directed to the Boston Society of Natural History, and containing a detaited account of the food required by two yommg robins, captured when about lialf grrown.

1s62. Flatig, Whaser. Utility of Birds. Massachusetts Agricultural Report. Istil, pp $70-78$.

Long essay on the economic value of birds with numerons notes on food habits of certain species, some of them from original observations.

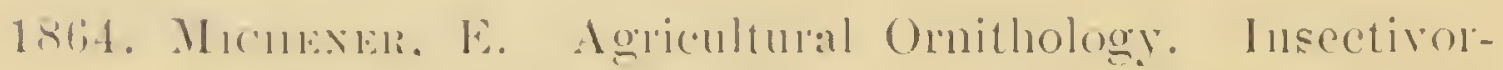
ous birds of C'hester Comnty, Pemeylyania. L. S.

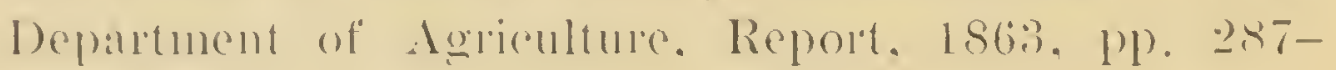
$\because 0 \%$

The value of birds to the agricultural interests discussed, and followed by a list of the birds of C'hester county, Penn., with the exception of the water species. Brief notes on the food and habits of each bird are given.

1864. Samtes, LA A. Mammalogy and Ornithology of New England with special reference to Agrenculural Eeonomy. L. S. Department of Agriculture. Report. lsti: Ple. $26.9-286$.

Ontlines of the classification of mammals, birds, and insects witl brief notes on the economic importance of each order from an agriculturai standpoint. Also a more general discussion of the relatious between the birels and nummals and the former, and the causes which tend to alter them.

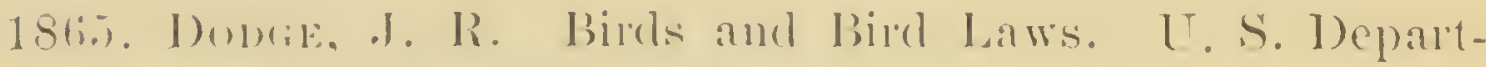
ment of Aerionlture. Report, 1 s(i.1, p. 481 .

'l'reats of the uses of birds, the necessity of a balance in animal production, value of birds as insect destroyers; the refutation of false charges against then and manner of protecting them; and gives in conclusion a digest of the bird and game laws then existing in most of the eastern and centrill states.

1865. Elı10T, D). (r. The "Game Birds" of the linited States. L. S. Department of Agriculture, Report, $1861,19.356-385$. 
An introduction defining the phrase "gane bird" as liere used followed by more or less lengthy discussions of the following species which he classifies under that head: Wild turkey, Mexican wild turkey, ocellated wild turkey, cock of the plains, ruffed grouse, Sabinc's gronse, allicd gronse, prairie hen, sharp-tailed grouse, Aretic sharp-tailed gronse, dusky grouse, Richardson's grousc, spruce grousc, Franklin's grouse, white-tailed ptarmigan, willow ptarmigan, Virginian partridge, Texan partridge, plumed partridge, California partridgc, Gambcl's partridge, scaled partridge, Massena partridge, woodcock, Wilson's or Englisl snipe and wild pigeon.

1S65. Sanuels, E. A. Oology of some of the Land Birds of New England. U. S. Department of Agriculture, Report, 1864, pp. 386-430.

A short discussion of the importance of Oology as indicating the brecding habits of birds is followed by slort accounts of above one hundred spccies which inhabit New England. The information given is almost exclusively confined to descriptions of eggs and accounts of nesting habits.

1866. Grover, Townend. Report of the Entomologist. Report of the Department of Agriculture, 1865, pp. 36-45.

A general synopsis of the insectivorous birds of North America, with account of the examination of stomachs of many of them. Included in the report of the government entomologist for 1865.

1866. Shmers, E. A. The Agricultural Value of Birds. Massachusetts Agricultural Report, 1865-'66, pp.94117.

An address on the valuc of the different groups of birds, with general discussion and citation of cxamples at lome and abroad.

1868. Hrcks, Isaac, Entomological items. American Entomologist, November, 1868, r. I, 1). 54.

Food hal,its of the Baltinore oriole.

1868. Samuels, H. A. Talue of Birds on the Farm. U. S. Department of Agricultule, Report, 1867, pr. 201-208. 
Notes on the economic importance of birds witl accounts of the examination of stomachs of the robin, various species of woodpeckers, cuckoos, erows, and jays; nearly all of the notes are apparently original.

1869. F. W. The Crow Blackbird a Robber. American Naturalist, v. II, p. 326.

A slort article including reference to fact that erow blackbird las driven out martins.

1870. Fowlis, Arousts. The Golden-winged Wroodpecker. American Naturalist, 1. III, pp. 42:3-427.

Economic status.

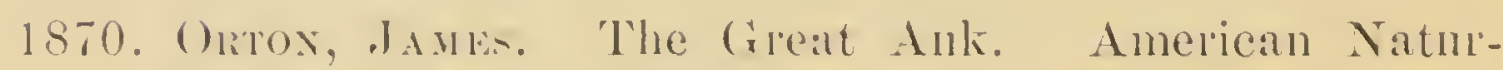
alist, 1. III, pp. $53,3-\overline{5} 42$.

Honle; foor; extinetion, ete.

1871. (ilorki, 'T'. Report of the Entomologist, L. S. Depatument of Agriculture, 1870, pp. 90-91.

Note on the economic value of birds in general and on the introduction of the English sparrow in partioular, included in the report on Entomology.

1872. Lockwoul, REY. SAmuer. The Baltimore Oriole and Carpentel Bee. American Naturalist. V. II, pp. 721$7 \cdot 24$.

Oriole removes head of bee and empties loney saek.

1872. Palmer, Fusk H. The Utility of Birds to Agricnlture. Massachusetts Agricultural Report, 1870-'72, p). $107-120$.

An essay on economic importance of birds, special reference being made to some thirty New England speeies.

1873. Prakixs, G. H. Birds in their Relation to Agricnltme. Vermont Agricultural Report, 1872, pp. 316$3: 37$.

A paper read before the Vermont State Board of Agrieulture, on the economic relation of birds. Abstracted in the report of the U.S. Department of Agriculture, 1873, p. 476. 
1873. Wurte, C. A. Woulpeckers tappling Sugar 'Trees. American Naturalist, v. III, P. I!)

Short article about red-headed woolpeckers rupturing the bark of sugar maples for purpose of obtaining the sap.

1874. Batwer, I. II., Jr. Birls. Thind Amunal Report Secletaly State P'omological Society of Michigan for 187:, P.). $127-128$.

Insect-feeding habits of several common singing birds of Michigan.

1874. Borce, Crrolaxe. 'The Robin. American Naturalist, v. VIII, PP. $203-208$.

Habits, food, nesting, broods, time of brooding.

1874. L.wng, J. W. 'The Value of Insect Eating Birds. New Hampshire Agricultural Report, 1878 , v. III, pp. .

Introduction, followed by a synopsis of families with chicf characteristics; a discussion on the food of birds with some apparcntly new data on stomach contents in a few instances and concluding remarks on the necessity of a proper balance, the usefulness of birds in general, and a plea for their protection.

1874. LrBarox, Wx. The Bird question. Transactions Illinois State Horticultural Society, 1873, r. VII, pp. $311-319$.

Discussion of the economic importance of birds.

1875. Palmer, Fraxk H. Insect Eating Birds, the Farmer's Best Fiends. Boston, Mass., Society Prevention Cruelty to Animals, $187 \%$.

A prize essay and an admirable discussion.

1875. Whenton, J. M. The Food of Birds as Related to Agriculture. Ohio Agricultural Report for 1874 $(1875)$, pp. 561-578 (Sept., 1875). Also reprint, repaged but otherwise unchanged, Pp. 1-18.

"This is in cffect a corrceted and completed list of the birds of Ohio, briefly ammotated, and with the general foor 
regimen of each family given; being a well-conceived essay of much practical utility." Coues, Bibliographical Appendix, Birds of Colorado Valley, 1S78, p. 716.

1876. Coles, Elliotr. The Destruction of Birds by Telegraph Wires. American Naturalist, r. X, pl. 734-736.

Many hundreds of thousands of birds killed. Instances cited.

1877. Altex, T. A. Destruction of Birds in the United States. Popular Science Monthly, r. X, p. 6336.

lieview of article by Mr. Allen in P'enn Monthly, condemning the wholesale shanghter of the herons in Florida.

1577. Anaow. A Voice Aganist the English Sparow from Indianapolis, Indiana. Forest and Stream, New York, v. 1111, 1877, P. 2061.

1877. Canr, A. G. Observations on the English Sparrow at Indianapolis, Indiana. Forest and Stream, New York, ง. VIII, 1877, p. 307.

1877. Catox. I. W. The Wild Tukey and its I)omestieation. Americam Naturalist, v. XI, pp. 3221-3:30.

The young; effects of domestication; chanacters of sexes; foorl; three principles of domestication.

1877. Caxix, Sintw.. On Changes of Hahit Among Woodpeckers. American Naturalist, v. XI, pp. 471-472.

Struggrle for life among bark-searching insects during rerent geologic ages, severe, ete.

1.878. I. Exolus. American Naturalist, Y. XII, Pp. 29-35.

The yuantity of food consumed by this bird.

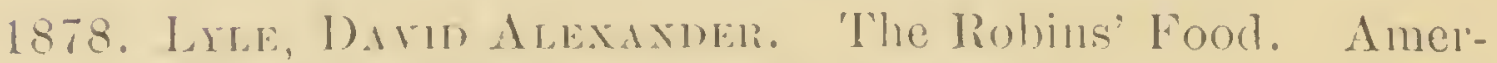
ican Naturalist, v. XII, P). 448-453.

Habits, quality, quantity.

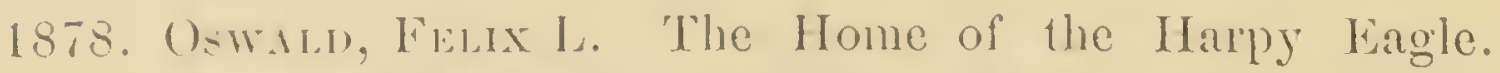
American Naturalist, $\because$ XII, p. 15j.

On the food of the liarpy eagle. 


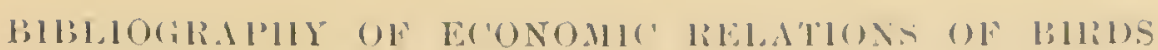

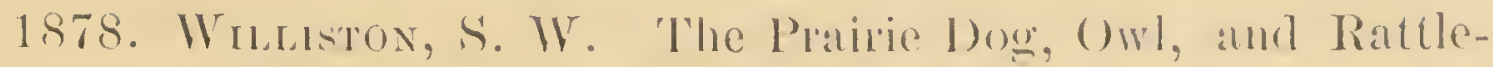
smake. Ameri('an Natmalist, N. XII, 1. 207.

The shore lark part of foor of the owl.

1880. Brawer, 'T. M. The Value of Birds. 'Transactions Illinois State Horticultural Society, 1879, r. XIII, P). $17: 3-178$.

Reprint of an address delivered before the Hingliam (Mass.) Agricultural and Horticultural Society, July 19, 1869, on the economic importance of birds.

1880. Cumuras, A. L. Morticultural Ornithology. 'Transactions Illinois State Horticultural Society, 1879, v. XIII, pp. $295-298$.

Discussion of the cconomic relations of certain of our native birds.

1880. Fonbes, S. A. The Food of Birds. Transactions Illinois State Horticultural Society, 1879, r. XIII, pp. $120-172$.

Discussion of the economic value of birds, followed by detailed account of the feeding liabits of the robin, catbird, brown thrush, wood-thrush, Alice's thrush, and Swainson's thrush; followed by a detailed account of the stomach contents of these birds.

1880. Fonses, S. A. The Food of Birds. Bulletin Illinois State Laboratory Natural IIistory, r. I, pp. $80-$ 148.

A general introduction discussing the necessity of a knowledge of bird food and methods of study, with extended records of studies of food of the thrushes and stone-chats.

1880. Forras, S. A. On Some Interactions of Organisms. Bulletin Illinois State Laboratory Natural History, r. I, Pp. 3-17.

A general discussion of the food relations of animals, with especial reference to birds and insects.

1880. Forres, S. A. Notes on Insectivorous Coleoptera. 13ulletin Illinois State Laboratory Natural IIistory, v. I, pp. 153-160. 
Feeding habits of ground beetles, with discussion of relation to birds.

1880. Wrister, F. M. Notes upon the Food of Predaceons Bectles. Bulletin Illinois State Laboratory Natural History, Y. I, PI). 14?-152.

Observations on food habits of ground beetles and others that birds feed upon.

1881. Aldricu, Cunkis. Value of the House Wren as an Insect Destrover. American Naturalist, v. XT, p. 318.

Hardiness, sociability, love of locality, wonderful fecundity, render it one of the most raluable of our insectivorous birds.

1981. Bumprs, II. C. 'The IIabits of the Jellow-Ibellied Woodpecker. American Naturalist. v. XY, p. Tiss.

A proof that they are sap caters, if not aiso bark eaters.

1SS1. Furbis, S. A. Supplenentary Report on the Food of the 'Thush Family. Transactions Illinois State Hor-

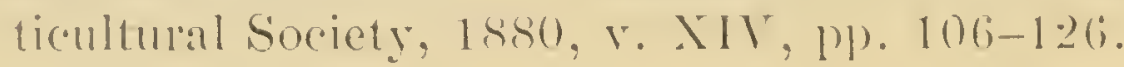

Comparison between earlier and more recent tables of the food of the thrushes of Illinois. (Transactions Illinois State Horticultural Soeiety, 1st9, v. Xill, pp. 120-172), with arlditional notes on the food of this family, followed by a detailed aceount on the food of the binebird.

1881. Lorkworn, Sintis. The kastern Snow Birl. Ameri(an Natulalist, Y. XY. p. iㄴ.t.

Note on exportation as a trade.

1882. All1:x, C. A. The Birds. New Hampshire Agrieultural Report, 1881, Pl). $269-282$.

Discussions on the following topies: Useful birds; warblers, fly-catchers, swallows, creepers, woodpeckers, and thruslies. Singular habits of birds; the cow buuting. Birds injurious to farmers; a list comprising the crow and blue jay, species of hawks (coopers, duck, pigeon, sparrow, sharpshinned, gas-, red-tailed, red-shouldered), and two species of owls (horned and earved). Plumage birds; descriptions of some of the brightest colored birds occurring in New Hampslire.

1852. Fonkes, S. A. The Ornithological Balance Wheel. 'Transactions Illinois State Horticultural Society, 1881, 
new series, v. XY, pp. 120-1:31. Extract Report State Horticultural Society, Michigan, 1881, 1). 20:3. Pacific Rumal Press, Jammary 21, 1842. Shawnee News, Februaly 13, 1882.

Relations of birds to army worms, canker-worns, and chinch bugs.

1852. Stadde, Fissua. Food of the Nestlings of Thurlus mi!rutorius. American Naturalist, v. XVI, p. 1007.

Animal food-insects in all stages of development-later broods all kinds of fruits growing in the garden.

1882. Stratiss, R. E. C. Wild Greese as Pests. American Naturalist, v. XVI, p. 326 .

Pull up the young wheatin the grain fields of the Upper San Joaquin-Valley, California.

1892. Wricatox, I. M. Report on the Birds of Ohio. Creological survey of Ohio, v. Ir, Pp. 187-628.

An elaborate report, with many references to economic relations. First published separately in 1879.

1853. Forbes, S. A. The Food Relations of the Carabidae and the Coccinellidae. Bulletin Illinois State Laboratoly Natural History, r. I, No. 6, pp. 33-64.

Record of studies with reference to food of ground beetles and lady-beetles, and their relations to birds.

1883. Folises, S. A. The Regulative Action of Birds upon Insect Oscillations. Bulletin Illinois State Labolatory Natural History, v. I, No. 6, pp. 3-32.

Results of investigation of food of birds in an orchard infested witlı canker-worms.

1883. Forbes, S. A. Birds in Relation to Agriculture. Stoddard's Encyclopedia Americana, v. 1, pp. 131-13.1.

A short discussion.

1883. Srane, Finsua. Kingbirds Feeding their Young upon Fruits. American Naturalist, v. XVII, p. 887.

The parents feed their young on fruit of honeysuckle, and when nestlings were able to fly they were conducted to bush and persisted until the plant was stripped. 
1883. Stearis, M. A. The Utility of Birds in Agriculture. New Hampshire Agricultural Report, 1882, pp. 219238.

An address on the economic importance of birds, treating of classification, utility of birds in ceneral, and certain species (blue jay, Baltimore oriole, ehickadee, white and red bellied nutliatch, etc.) in particular, and the utility of birds in migration.

1883. Storke, F. H. A Caterpillar-eating Henhawk. (Buteo pemmsyleanirns) Science, No. (i, v. 1, p. 168.

188:). Sumks, .J. On the Winter Food of the Partridge and on Partridge Poisoning. Procectings and 'Transactions Nora Scotian Institute Natural Science, V. V'l, Part 1, 1). $78-81$.

1883. V.x Okix, A. (i. 'The Hairy Woodpecker. American Nituralist, v. XVII, P). 511-51:).

Refurenee to eechomie value.

1884. Ammicu, Cmalus. Notes on the Redwing Blackbirl. American Naturalist, 1884, v. XVIII, pp. 309, 310.

On its nesting labits and decrease in numbers through the reelamation of wet lands.

1884. Birds and Electric Light. Forest and Stream, r. XXII, p. 124 .

Extract from the Winona (Minnesota) "Republiean" of May 2:?, 18s4, giving account of the lestruction of large numbers of birds killed by striking argainst eleetric liglits during two nights, May 20 and 21, at Winona, Minnesota.

1884. Brixk. Fruiteating Birds. Forest and Stream, r. XXII, p. 24

Arraignment of the robin and catbird.

1884. Canonx, .J. C. Protecting Song Birds. Forest and Stream, r. XXII, p. 203.

In defence of collecting for scientific purposes. In the same heading is a protest by 11 . W. C. against indiscriminate egg collecting by boys "as a business," but in favor of collecting for scientific purposes. 
1884. Culbu, A. B. Birls and Electric Lughts. Forest and Stream, v. XXII, 1). 26.

List of specios pieked up at the foot of electric light masts in Cincimati, Ohio.

1884. (Coopki), C. (V.) Insertivorous (ilouse. Camadian Sportsman and Naturalist, v. III, p. 26il.

A specimen of the ruffed grouse (Bonasa umbellus), found to have its crop full of caterpillars of Notodonte concinne, commonly knowu as the red-humped apple-tree caterpillar.

1884. Commes, A. L. Ornithology. 'Transactions Illinois State Horticultural Society, 1883, v. XVII, pp. 202206 .

Notes on habits of birds and difficulty of correct determination of species in all cases.

1884. Cumpurgs, A. L. Migratory Birds. Transactions Illinois State Horticultural Society, v. XVII, lp. 163-165.

Notes on bird migration in Illinois.

1884. C. E. B. Utility of the Crow. Forest and Stream. Y. XXII, P. 424.

1884. Editorial. The Sacrifice of Song Birds (fol millinery purposes). Forest and Stream, r. XXII, Aug. 7, p. 21.

1884. Editorial. Domesticating Game Birds. Forest and Stream, v. XXI, No. 14, p. 264.

Notes on the ruffed grouse, the pintail grouse, and the common quail.

1884. Editorial. The Destruction of Small Birds. Forest and Stream, v. XXII, p. 24.

Statisties relating to the appalling magnitude of the millinery trade in bird skins.

1884. G. M. S. The Migratory quail. Forest and Strean, r. XXII, p. :38\%.

Birds turned loose at Springfield, MLass., two years ago. have raised young, and are still there, and are there to stay. 


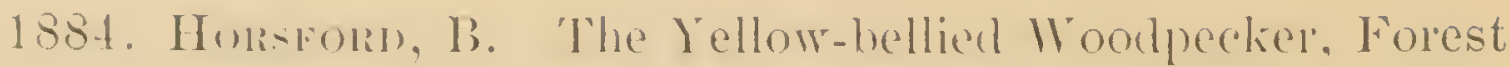
and strean, Y. XX. No. T, p. 121.

Kills trees by girdling them.

1584. Mirix. Protect the Small Birds. Forest and Stream, Feb. 2.8, p. sis.

Against the "mania" for possession of immense series of birds' eggess and skins.

188t. Nessucck. Robins and strawherres. Forest and Sitream, r. XXII, Sept. 25, p. 164.

Verdict heavily analinst the robin.

1884. Nok, Furcule M. Are Owls Beneticial to the Famer? Also notes on the species in Indiana. Indiana fiamer, July 5, 1584 .

1854. Pukkt Frut Eating Birds. Forest and Stream, v. XXII, Alg. 28, 1. 83.

Statistical table showing contents of stomachs of varions species.

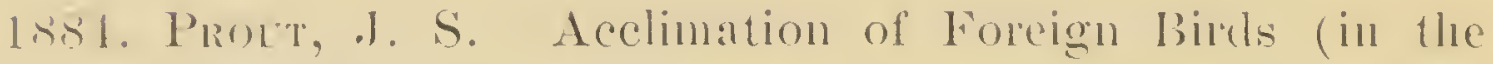
Enited States). Forest and stream, Y. XXII, p. 364.

In view of the unsuccessful atempts with the Enropean quail, skylark, otc., it is sugrested that such birds should he turned out in the sonth (Florida, Lonisiani, Mlexieo) instearl of the North.

1sit. R. 'T. The Rohin as a Game Bird. Folest and stream, r. XXII. Sept. 1, p. 10.)

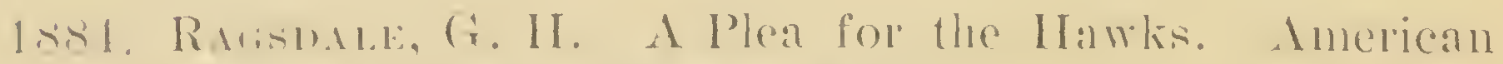
Fielr. Y. XXI, March 2.2. p. 2.s1.

Irong diserimination in the slanghter of the birds, the sreater part of which are henoficial, hley subsisting chiefly mpon moxious mammals and insects.

list. [Special.] Smali bind bestuction. Fonest and

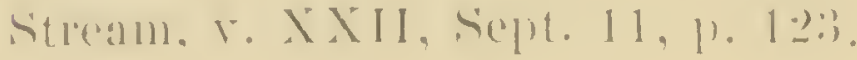


Forty thousand tern skins taken in Massachusetts sent dnuing the past year to Liverpool ior millinery purposes. Conlment also on the destruction of woolpeckers and other small birds, which fall victims to the grmning craze.

1884. Warkex, Mankr. I)iumal Rapacious Birds. (With special reference to Chester county, Par.) Agriculture of Pennsylrania, 1883 (1884), pp. 96-112.

A very important paper on the food of various hawks, with report of numerous examinations of the contents of stomachs.

1884. Weil, Chalence M. Does the Crow Blackbird eat Crayfish? American Naturalist, v. XVIII, p. 832.

Part of a crayfish was found in the stomach of a young crow blackbircl.

1884. Ween, Charence Moores. The Food of Young Birds. Report Michigan State Board of Agriculture, 1884. Also Report Michigan State Horticultural Society, 1884.

Report on food of nestling catbirds, robins, bluebirds, and crow blackbirds, with discussion of economic relations.

1885. Barnes, G. L. Kingbirds and Bees. Forest and Stream, r. XXV, Oct. 8, p. 205.

1885. Benvett, Geo. 13. The Lesson of a Market. Forest and Stream, v. XXIV, June 4, pp. 366, 367.

All account of the small birds exposed for sale in the market at Norfolk, Va.

1885. Brown, E. L. An Insectivorous Kite. 'The Naturalist, r. I, No. 3, p. 125

1855. Butrki, A. W. 'The C'uckoo. Inciana Farmer. April, $1855, \mathrm{p} .14$.

1855. Drky, Cins. Notes on the Food of Raptorial Birds. Jommal of Cincimnati Society of Natural llistory, r. Vill, ply. (je-bit. Also reprinted in Randon Notes oll Natural History, r. I, No. s.

Notes on the contents of stomache of varions species of lawks and owls. 
1885. Harwant), R. Curious Food of the Kingfisher. Auk, r. 11,1$) .311$.

Found in stomach, fragments of various beetles belonging to the families Carabida, Dytiscidae, and Scarabaidar.

1885. Norıl, G. Destructive Electric Light Towers. Forest and Stream, r. XXr, Nor. 12, p. 305.

During a rainy night in October 10; birds were picked up nuder one light tower in Savamal,, Ga.

1885. Nok, Fletchen Mr. The Value of Birds as Insect Destroyers. Indiana Fanmer, Jan. 17, 1885. (Abstract of paper before State Board of Agriculture.)

185.). Warrix, B. H. Blackbird's Food. Facts from the dialy of a lield-working naturalist, showing the piscivorous habit of two species of the genus (quiscalus. Agriculture of Pennsylrania, Report for 1885, pp. 157 159 .

Statistics of examinations of stomachs of numerous specimens of Quiscalus purpureus and Quisculus major.

1985. Waklix, H. H. Birds' Foorl. Agriculture of Pennsylvania, pp. $150-156$.

On the food of robin and catbird.

1885. X. Foreign Crame Birts in America. Forest and Stream, r. XXV, September 3, pr. 103, 104.

An important historical paper on the subject.

1836. Anlik, Chas. F. That 'Thieving Rice Bird. Forest and Stream, r. XXYI, No. 15, November 4, pp. 283 , 28.1.

On its probable utility as well as destructiveness.

1886. Bow est and Stream, r. XXVI, p. 5, Jan. 28, 1886.

1886. Butrki, A. W. The Periodical Cicada in Southeastern Indiana. U. S. Department of Agriculture, Division of Entomology, Bulletin No. 12, pp. 24-31.

Refers to birds known to eat cicadas. 
1886. Chapman, Frank M. Birds and Bomnets. Forest and Stream, r. XXVI, No.6, February 25, p. 81.

List of birds seen on ladies' hats in an afternoon's walk in New York city.

1886. Duri, Chas., Fisher, W. H., Warden, R. H., LaxqDox, F. W. JAnes, J. F. Papers on the Destruction of Native Birds. Jourual of the Cincinnati Society Natural History, r. IX, pp. 163-224.

1886. Editorial. A Use for Falcony. Forest and Stream, r. XXVII, No. 13, October 21, p. 241.

'Trained hawks suggested' as a means of protecting rice fields from the depredations of the rice birds.

1886. Editorial. Snipe Decoration. Forest and Stream, v. XXVIT, No. 15, Norember 4, p. 281.

Use of snipe and migratory game birds for millinery purposes in lieu of song birds.

1886. Grint, W. G. 'The 'Terns of Matinicus Rock (Coast of Mraine). Forest and Stream, r. XXYII, No. 25, January $13, \mathrm{p} .485$.

On the wholesale slaughter of terns at this point for millinery purposes by C. E. Cahoon, of Taunton, Mass., during the season of 1886.

1886. Miller, Waryer. Ravages of Rice Birds. Conglessional Record, 49th Congress, June 11, 1886, p. 5747.

A loss of $\$ 6.87$ per acre by the rice birds to the rice crop and the total annual loss to one plantation is estimated at $\$ 8,2.50$.

1886. Nor, Fretcues M. Notes on the Destruction of Indiana Birds for Millinery Purposes. Indianapolis News, Feb. 22, 1886 .

1886. 'Thonpos, Marres. Some Song Birds of Indiana. Report of the State Bourd of Agriculture, 1885, pl). 247-252. 
1887. Finnli, Hu. H. The Canalal Cirouse. Tommal Cincimnati Society of Xatulal Ilistory. Y. X, pp. 2(1.)-206.

Some remarks as to its searcity, fearlessmess, habitat, and its feeding on the tamarack.

1857. Hay, (). P. The Red-leaded Woodpecker a IIoarder. The Auk, v. IV. 1, 1!:

An insect-eating species, and during winter avail themselves of grain, grass seeds, and softer muts. Some eat fruit and berries.

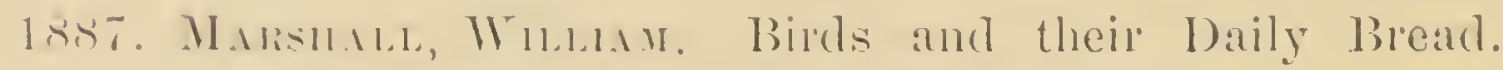
l'opular Sorence Montlily, v. XXX, p. 600.

Food of birds very diversitied.

188\%. Mrisisu, 1)r. (. I1. Report of the Ornithologist and Mammalogist. U. S. Department of Agriculture, Report, 1886, 1). $227-258$.

Notes on importance of subject, progress of work and copies of eircular letters sent to various classes of agrienlturists throughout the eomntry. Extracts from the answers received have served as the basis for article on the English sparrow, its introluction, rate of increase, rate of spread, relations to other birds, and economic importance as an enemy to the gardener and frmit grower, effects on agriculture, failure to rednce the numbers of caterpillars, and recommendations for protective legislation. On the rice bird, its ravages and habits, and on the distribution and migration of birds.

1888. Alixinter, (i. E. Trochilus Colubris killed by a Mantis. Procecliugs of Elliott Society of Science and Art. r. II, May, 1888, pp. 195-196.

188. Arem. W. C. Crame Destroying Hawks. The Ameri('an Fiell, v. XXIX, p.

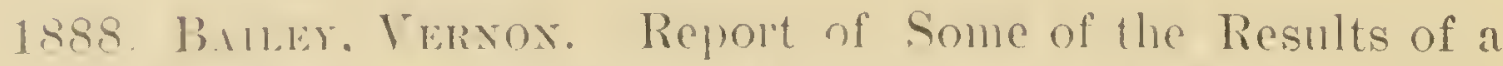
Trip throngh Part of Minnesola and l)akota. U.S. Department of Agriculure. Ammual Report, 1887, p. $4: 26$. 
Notes on damage done by the yollow localed hatekhind hy

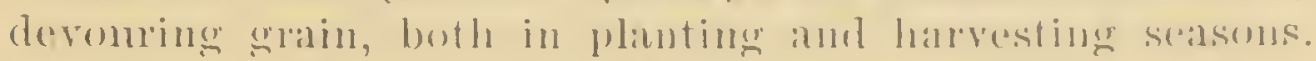
Also notes on distribution and hal,its of red-winged blateklimel, purple arackle, Brewer's blackbirl, cow bird. bobolink, and Franklin's gnlll.

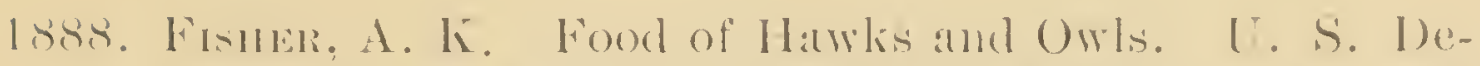
partment of Agrieulture, Ammal Report, 1857, pl. $402-422$.

Statements of the stomach contents of more than 1,(1)00 lawks and owls. The following species are mentioned: Swailow-tailed kite, Mississippi kite, marslı lawk, sliarpslinned lawk, Cooper's liawk, goslawk, red-tailed hawk, red-shouldered liawk, Swainson's hawk, broad-winged liawk, rough-legged hawk, golden eagle, bald eagle, prairie falcon, dnck liawk, pigeon hawk, sparrow hawk, barn owl, longeared owl, short-eared owl, barred owl, Florida barred owl, sawwlet owl, screech owl, great horned owl, snowy owl, hawk owl, and burrowing owl. Only a few of thesespecies were found to be injurious.

1888. Fisner, A. K. Experiments in Poisoning. L. S. Department of Agriculture, Amual Report, 1887, pp. $42: 3-426$.

Details of experiments with strychnine and arsenic in various forms and corrosive sublimate as poisons for birds.

1888. Warrex, B. H. Report on the Birls of Pennsylrania, with special reference to food habits. Harrisburg, 1888, pp. I-XII, 1-260.

An elaborate report based on the examination of over three thousand stomachs. Illnstrated with fifty plates. A revised and enlarged edition covering 450 pages was published in 1890. 'The notes on food materials are musmally complete.

1889. Bakli, C. F. Notes on the Food of Birds. Proceedings Academy of Natural Sciences of Philadelphia. pp. $266-270$.

Upwards of 300 stomachs examined in Florida.

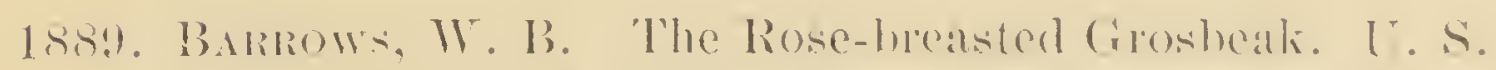

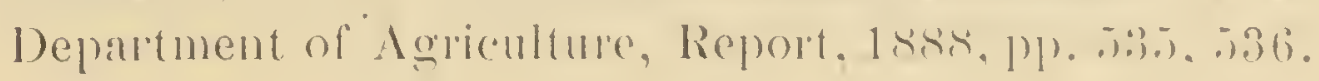


Extracts from correspondence tend to prove this species a valuable friend to the farmer from the fact of its feeding freely on the Colorado potato beetle.

1889. B.trRows, W. B. The Food of Crows. U. S. Department of Agriculture, Report, 1858, pp. 498-535.

Short introduction followed by a long discnssion on both the common and fisl erow, with many extracts from correspondence. Information has been collected on distribution of the crows, injury to various eereals, damage to other crops, other vegetable food, distribution of noxious seeds, as a destroyer of eggs and young of poultry and wild birds, insect food, as an enemy to grasshoppers, as an enemy to potato beetles, insect food as revealed by an examination of the stomachs, as an enemy to field mice, miscellineous animal fool, and as at scavenger. The pilper is closed by the results in detail of the eximination of a lare number of stomachs of the common and a few of the fish crow.

1S8.9. Bhatentir, W. S. On Feathered Friends of Indiana. A series of live articles in Indiama Farmer, moler dates of May 4, May 18, May 2.). and Nor. 2:3, 1889, and March 29, 1890.

1889. Fisner, A.K. The Sparow Hawk. U. S. Department of Agriculture, Report, 1 siss.

Range and habits, extract from correspondence and account of the contents of $16: 3$ stomachs from various localities.

1889. Fismer, A. K. The Shorteared Owl. I. S. Department of Agriculture, Report, 18s8, pp. 496-498.

Short account of the liabits and food of this species, with extraets from correspondence.

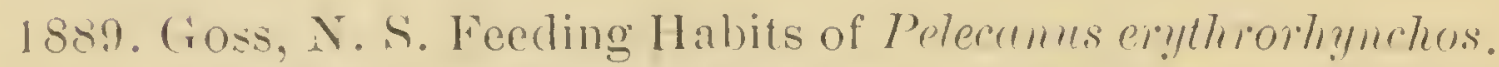
Transactions Kimsas Academy of Science, v. XI, pp. 11. 12. See also 'lhe Ank, r. Y, Pp. 25-27.

185:. Merrum, C. H. Introduced Pheasants. T. S. Wepartment of Agriculture, Report, 1888, pp. 484-4s8.

Account of the introrluction of certain game birds into the western portion of the United States, and extract from correspondence in regard to them. 
1889. Strode, W.S., M. I). Foor of the (Owls. American Naturalist, v. XXII, Pp. 17-2t.

Treats especially of great horned owl.

1889. Wright, Jula McN. The Shrike. Science, r. XYII, p. 217 .

Feeding habits.

1890. Brunler, II. II. How the Cooper's Hawk Hunts its Prey. Ornithologists' and Oologists' Semi-Annual, r. II, pl. $32-34$.

1890. Cook, C. B. The English Sparrow. Michigan Agricultural Experiment Station, Bulletin 62, May, 1890.

General notes on English sparrow; description; native birds likely to be mistaken for it, and means of destruction.

1890. Couper, Wr. Food of Woodcock. Shhooting and Fishing, r. VIII, No. 2, p. 28.

1890. Couper, ITr. Food of Whoodcock. Shooting and Fishing, v. VIII, No. т. pp. 131-132.

1890. Cocper, Wr. 'The Food of Woodeock. Shooting and Fishing, r. V', No. 23, p. 458.

1890. Fisnex, A.K. 'The Marsh Hawk, Screech Owl, and Flammulated Screech Owl. U.S. Department of Agriculture, Report, 1889 , pp. 370-376.

Discussion of the distribution and havits of these species, with extracts from various publications.

1890. Sint Cronx. The Food of Woolcock. Shooting and Fishing, v. I, No. 25, p. 488.

1890. Sant C'ronx. Food of Woodcock. Shooting and Fishing, v. YIII, No. 4, p. 70.

1891. Bankows, W. B. Seed Planting by Birls. U. S. Department of Agriculture, Report, 1890,1$)$ p. $280-285$.

Discussion of the subject in various phases and statement of some of the problems to be solved. 


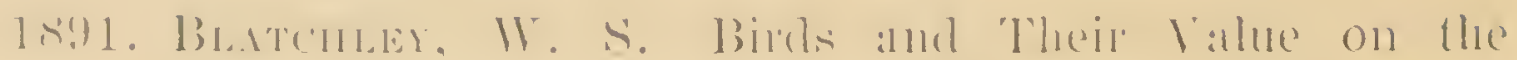

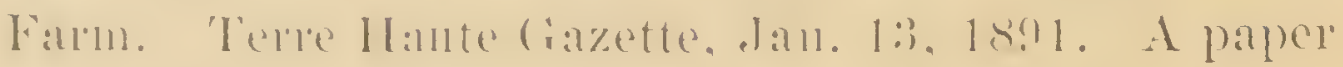
read before the Vigo (annty Fambers Institule.

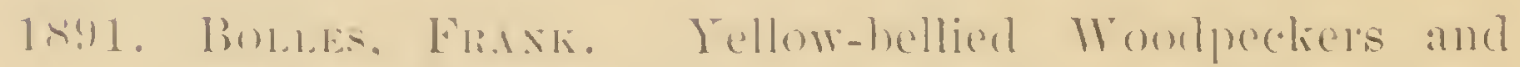

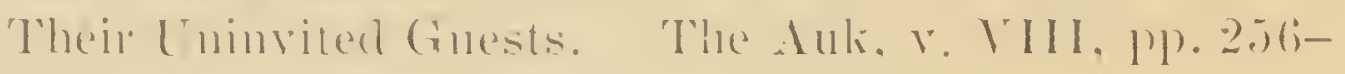
27() .

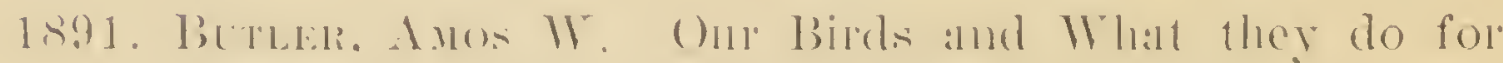
the falluele. Repolt state Boald of Agriculture, In-

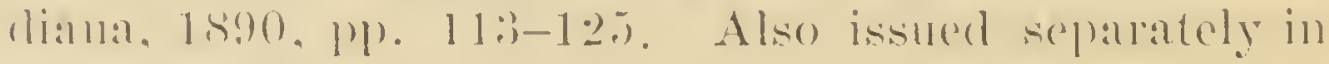
p:amphlet form.

1591. Markir, (ivo. II. Ilabits of the ciolden Plover, (Cheromines dominicus), in Massachusetts. The Ank. ․ VIII, Pl). $17-2.4$.

With paragraplo on feeding hahits, pr. 1s, 19.

1891. Mekir, Gien. H. Habits of the Seoters. 'The Auk. v. VIII, PI). 2.;(i-2)7().

18:91. Mrisinu, I)r. C. H. Birels which Feed on Mulherries. L. S. Department of Agriculture, Report, 189()$, 1$. 2s.5.

List of twenty-six species of birds which had been observed by Dr. A. K. Fisher aud the anthor feeding upon mulberries.

1591. Rass, Cant. 'Talie Care of the Birds: Popular Science Montlily, r. XXXIX, p. 685.

A plea for bird protection.

1892. Bexnme, C'mantas. Life Histories of North American Birds. Washington, U. S. National Mnsemm, Special Bulletin, No. 1.

Elaborate accomnts, with special reference to breeding habits and egurs of the gallinaceous birds and the birds of prey. Ergs illustrated in twelve plates. Many references to feeding labits.

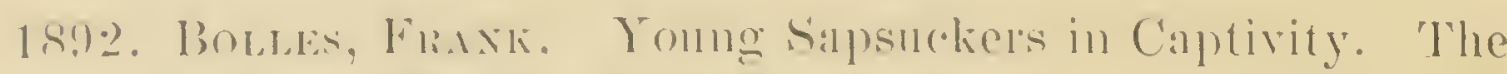
Ank, v. IX, 1)! $1(1 !)-11 !$. 


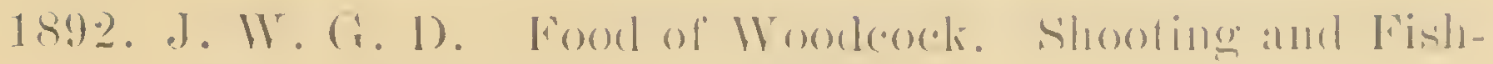
ing, Y. XIII, No. T, ए. 12!?.

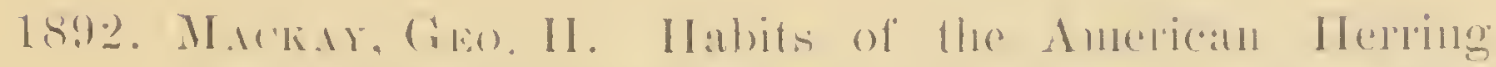

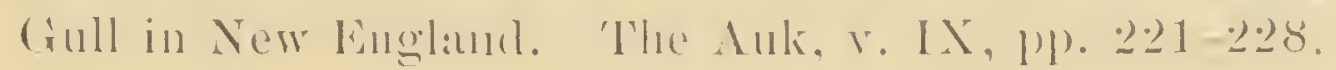

Contaius a fow remarks on feeding habits.

1892. Mnlk:1. II. II. Food IIabits of Hawks and ()wls in Mayland. Shooting and Fisling, r. XII, No. 19, p. $: 366$.

1892. Wricox, E. V. The Food of the Robin. Ohio Agricultural Experiment Station, Bulletin 43, September, $1892, \mathrm{p} \cdot 115-131$.

Details of a somewhat extended sturly of the food of the robin as indicated by a study of stomach contents. A total of 187 stomachs were exanined of bircls killed during the spring and summer months. In the summary it is estimated that the beneficial species of fruit and insects eaten will amount to 52.4 per cent. of the total, the injurious to 18.6 per cent., while the remainder consists of species of which the economic importance is as yet unknown.

1893. BARrows, IT. B. The Food of the Horned Larks ol Shore Larks (Otocoris). U. S. Department of Agriculture, Report, 1892, pp. 193-197.

Account of the examination of the stomachs of fifty-nine horned larks, and summary of results.

1893. BEAL, F. E. L. Food Habits of the Cedar Bird. U. S. Department of Agriculture, Report, 1892, pp. 197-200.

Account of the examination of 12:) stomachs of the common cedal waxwing, with a short summary of the result.

1893. Brewstik, Wu. A Brood of Young Flickers and how they were Fed. The Auk, r. x, pip. 231-236.

1893. Butlik, A. Wr. Further Notes on the Evening Grosbeak. The Auk, r. X, Pp. 15.5 157.

General notes with references to fechine. 
1893. Editorial. Feathered Wromen. The Times, London, England, Oct. 17, 1893.

Leading article protesting against use of birds for millinery purposes.

1893. Fisner, A. K. The Hawks and Owls of the Inited States in their Relation to Agriculture. U. S. Department Agriculture, Division Ornitl. and Man., Bulletin No. 3, 1893.

A remarkable volume of more than 200 pages, with full discussion of feeding habits of each species, and a colored plate illustrating its appearance.

1893. Hoxt, Jaxi: L. Birds that Befriend Our Forest Trees. A series of chapter's iregularly published in the Farmers' Guide, Huntington, Indiana. Chapter I in r. I, No. 1, January 1 ; clapter II in v. I', No. 2, Jamuary 15; chapter 111 in v. V, No. 3, February 1 ; chapter Ir, in r. V. No. 4, February 15 ; chapter $\mathrm{T}$, in r. $\mathrm{T}$, No. 6, March 15; clapter YI in r. Y, No. 27, Dec. 15.

18:93. Lecs. F. A. Food of Humming-birts. The Auk, r. X. p1).311-315.

1893. McLotrin. C. I). Protection of Birds from the Boys. Science, $v$ XXII, Pl). $347-348$.

Recommends for schools (1) Punishment of guilty by law; (2) Teaching of sentiment; (:3) Close study of birds; (4) Orẹaniming societies for bird protection.

15:93. Snltentr. R. W. Some Recent Economic and Scientifie (zuestions in Oruthology. Science, $v$ XXI, pp. $255-2.56$, Nor. 16, 1893.

Discusses causeg for recent decrease in birds aromd large cities and remedial measures and legislation.

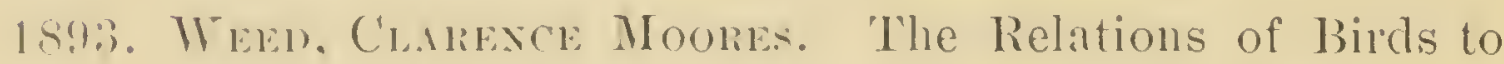
Camirorous Insects. Proceedings Society Promotion Agricultural Science, Fourteenth Meeting, pp. 70-74.

A general discussion showing incorrectness of calling all parasites and predaceous insects beneficial. 
1894. Barrows, W. K. Food Iabits of the Kinghind or liee Martin. U. S. Department of Agriculture, Report $1893, \mathrm{PP} .233-234$.

Brief discussion of range, habits, and food as indicated by a study of the stomach contents.

1894. C.no, F. W. Birds Injuring Apples. Garden and Forest, v. VII, P. 114.

Brief mention of birds attacking the fruit.

1894. Hune, Jaxe L. Farmers, 'Take Care of your Birds. 'The Farmer's' Guide, Huntington, Indiana, v. VI, No. 10, May $15,1894$.

1894. Smyth, E. A.', Jr. Are all Birds of Prey Injurious to the Farmer? Virginia Agricultural Experiment Station, Bulletin 38, pp. 23-39.

Notes on the feeding habits of the common hawks and owls of Virginia, largely compiled from "The Hawks and Owls of the United States."

1894. 'Troop, Janks. Protecting Fruit from Birds. Purdue University Agricultural Experiment Station, Bulletin 53 , pp. $125-126$.

Details of an experiment in the use of netting to protect cherries from the attacks of birds, in which it was shown that the saving from its use would pay for the original cost the first year, under conditions in which the fruit is obliged to remain upon the tree until ripe.

1894. Winship, A. E. Bird Day. Journal of Education, May 24,1894 .

Account of observance of bird day in schools of Oil City, Pa.

1895. 'The Ameriean C'row. The Wilson Orrithological Chaptel of the Agassiz Association, Bulletin No. 5, March, $1895, \mathrm{pp} .5-42$.

Notably feeding, nesting, roosting, llight, relative abundance. 


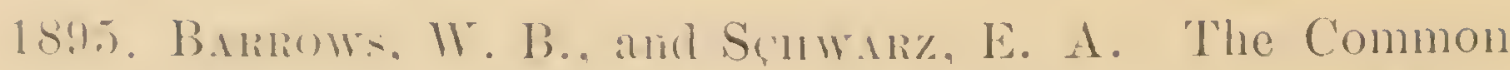
Crow in the United States. U. S. Department of Agriculture. Division of Ornithology and Mammalogy, Bulletin No. $6,189)$, p. 98.

General habits of the crow, geographie distribution, migration, erow-roosts; animal food of the erow; methods of investigation, methor of examining stomachs; relative percentages of amimal and regetable food; relation of the crow to mammals: relation of erow to other birds; relation of crow to reptiles, fishes, and invertebrates; insect food of the crow; testimony of eorrespondents on insect food by the crow; vegetable food of the crow, eorn, wheat, oats, barley, buckwheat, mast, grass, and weed seeds, wild rice, fruit; protection of crops, -timring corn, use of poison, bounties: list of localities at which erows's stomachs were collected.

1S!5. Bkat, F. E. L. Crow Blackbirds and Their Food. U. S. Department of Agriculture, Year Book, 1894, pp. $2: 3:-248$.

Discussion of the purple grackle and its two sub speeies, the bronzed and Floridi grackles. The following subjects are treated: Creoglaphic range, observations regarding the diet of the crow blackbird, examinations of stomaeh contents, various articles of bird diet, grains and fruits as blackbird food, seeds as bird food, food of the young, and smmmary.

18.5.) Brat, F. E. L. Preliminary Report of the Food of Woorlpecliers. L. S. Department of Agriculture, Division of Ornitholong and Mammalogy, Bulletin No. 7. pl. 1-3:. Rev. in Amer. Nat. Y. XXX, p. 946; Pop. Ne. Montlily, Y. XIIX, 1). 573.

Gencral remarks and table showing food percentages, followed hy short discussions of the range, habits, and food of the following species: downy, hairy, red-headed, red-bellied, and pileated woodpeckers, lliekrer, and yellow-bellied sapsilckel.

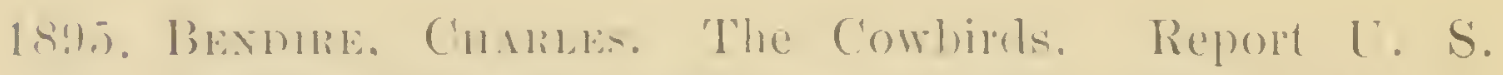

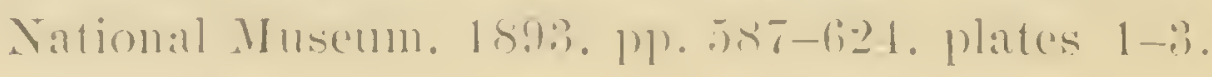

Extended aceomt of the life history of various species of cowlirels, with especial reference to their relations to other biris. 


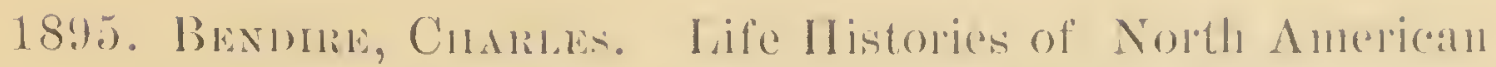
Birds, from the Parrots to the (Arackles. Wrashington, Smithonian Contributions to Knowledge, 985, 1595.

A contimnation of the work listed above (1592), with many references to feeding habits.

1895. Bustruter, W. S. Protect the Woodpeckers. Indianapolis Sunday Journal, Oct. 27, 1895.

1895. Fismer, A. K. Hawks and Owls as Related to the Farmer. U. S. Department of Agriculture, I'ear Book, 18.4, pp. $215-232$.

Discussion of the economic importance of the birds of prey, taking up the subjects of cause of the prejudice against birds of prey, some characteristics of rapacious birds, food habits of the principal birds of prey, harmless species of hawks and owls, wholly beneficial hawks, hawks and owls mostly beneficial, and harmful hawks and owls. All the common North American species are discussed.

1895. Formusn, E. H. Birds as Protectors of Orchards. Massachusetts Crop Report, Bulletin No.3, Series of 1895, pp. 20-32. Also in Report Ont. Ent. Society, 1895, рр. $5: 3-62$.

Notes on feeding habits of the chickadee, nuthatch, browncreeper, downy woodpecker, and other's. Especial attention is given to the chickadee.

189.). Matr, F. H. Birds, Fruits, and Flowers. National Stockman and Farmer, 1895, p. 559.

Discussion of value of birds to fruit-growers. Experience with Russian mulbery in attracting birds.

1895. Husos, W. II. (Bird Protection and the Clergy.) English Society for Protection of Birds, letter to Clergy, November, 1895. Reprint by Wisconsin גudubon Society, 18.18.

Discussion of use of birls for millinery purposes.

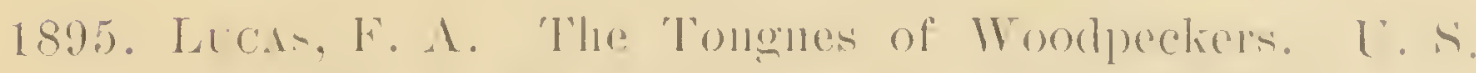
Department of Agricolture, Division of ()millology

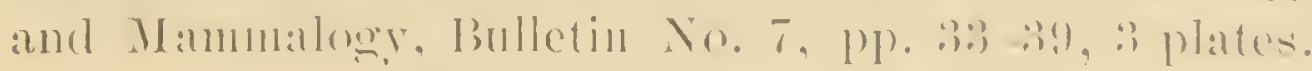


Discussion of the anatomy of the tongues of the various species of woodpecker's, the variation in form and relation of the tongue to the food.

1495. WeEn, Chaliexe M. 'The Robin. 'The Mirrol and Farmer (Manchester, N. H.). Oct. 4 and 11, 1895.

A discussion of economic status of the robin.

1895. Waxime, A. E. Bird Day. The Outlook, April 6, $189 \%$, p. j60.

Account of original bird day at Oil City, Pa, on the first Friday in May, 1894. Plea for general adoption.

1896. Barcock, C. d. Birr 1)ay. Jommal of Enucation, April 4. 1896.

1696. Heal, F. L. L. The Meadow Lalk and Baltimole ()riole. U. S. Department of Agriculture, Year Book, 1895, pp. $419-430$.

Brief notes on distribution and habits of the two birds, followed by statements of their food as indieated by the examinations of a linge number of stomachs. Almost three fomrths of the food of the meadow lark was found to consist of insects, and of these a very large per cent. were grasshoppers and crickets. 'The accusation of pulling sprouting grain and feeding upon grain gencrally appears not without basis, but the damage done in this mamnel is more than comnterbalanced by the numbers of insects eaten. 'The food of the oriole was fomol to consist almost exclusively of insects, and these to a large extent of noxious species. No question can be raised as to the value of this bird as an insect destroyer.

1896. Butrki, A. W.. Indiana. A Century of Changes in the Aspects of Nature. President's address. Proceedings of the Incliana Acarleny of Seience, 1895, pp. $: 31-4:$.

Refers to changes in avifamm.

1896. Cunxiser. F. .J. On Feathered Beanties. Indiana Famer, Feb. 15, 18.96. 1). 6 .

1896. Fonmsu, E. II. The Crow in Massachusetts. Massachusetts Board of Agriculture, Crop Report Bulletin, 1896. No. 1, 1). $24-40$. 
General notes on the Anerican crow, nilgration, gregarions habits, mating and nesting habits, digestive capalcity, food, the protection of crops, summary.

1896. Haxe, Jane L. Cedar Waxwing. Farner's (inide, v. VIII, No. 12, June $15,1896$.

1896. Haxe, Jaxk L. Farm Birds in Northern Indiana. The Farmer's Guide, Huntington, Incl., r. VIII. A series of articles in chapters in the following numbers of that paper: No. 3, Feb. 1, 1896 ; No.4, Feb. 15; No. 5, March 1; No. 6, March 15; No. 7, April 1; No. 8, April 15; No. 9, May 1.

1896. Junn, S. D. The Food of Birds. American Naturalist, r. XXX, pp. 1050-1051.

Catbird, brown thrasher, and house wren. Wren exclusively insectivorous and highly valuable in agriculture. Catbird and thrasher have a mixed diet, 63 per cent. animal in thrasher, 44 in catbird. Bulk of food of mocking bird appears to be animal.

1896. Krrklaxn, A.H. The Army Worm. Massachusetts Crop Report, July, 1896, p. 35.

List of ten birds feeding on army worms: Kingbird, phœbe, bobolink, cowbird, red-winged blackbird, Baltimore oriole, crow blackbird, English sparrow, chipping sparrow, robin. Probably also meadow larks, crows, tlickers, quail.

1896. Orerholser, H. C. A preliminary list of the birds of Wayne county, Ohio. Ohio Agricultural Experiment Station, Bulletin No. 4, 'Techuical Series, pp. 243354.

Notes on 183 species of birds known to inhabit this region, togrether with a list of the species thought to be occasional visitors. Notes on food of a few species.

1896. Palner, T. S. Bird Day in the Schools. U. S. Department of Agricuiture, Dirision Biological Survey, Circular No. 17.

History of the movement; discussion of object and value. 
1896. Richards, Harmet. 'The Birds at Dinner. Popular Science Monthly, v. XLIX, p. 337.

Nearly all birds feed their young on insects, worms, or some form of animal food, and also depend mainly on that food for themselves at that busy season, although at other seasons their favorite food may be grains and berries.

1896. Warkex, B. H. Onl Home Birds. Pennsylyania Agricultural Experiment Station Report, 18.95, Pl). $244-$ 265.

Popular acconnt of the birds of Pennsylvania and discussion of the value of birds as destroyers of vermin and the danger of destroying them.

1896. Whamex, 13. H. 'Taxidermy; How to Collect, Skin, P'reserve, and Momnt Birds. Pentsylvania Depantment of Agriculture, Inivision of Economic Zoölogy. bulletin 6. 1). 1ㅗㅗ.

A condensed account of methods for collecting, skinuing, preserving, and monnting birds; followed by the game laws of the state.

1897. Axtmoxy, A. W. 'The Roadrumer as a Destroyer of C'aterpillal's. The Auk, r. XIV. P. 217.

hoadrunners in California feed on caterpillars of Ayraulis ranilla, which attack leaves of passion vines.

1897. Banter, Wu. L. Disgorgement of Cherry Stones again Noted. The Auk, r. XIT, Pp. 412-413.

Cherry stones discrorged by young robins, catbirds, and wood robins (thrush?).

18:17. Bral. F. F. L. Recent Investigations of the Food of European Birds. 'The Auk, v. Xl', pp. 8-14.

Review of papers by Hollrung and Gilmour; remarks on methods of estimating percentages of food.

1897. Bear, F. E. L. The Blue Jay and its Food. U. S. Department of Agriculture Year Book, 1896, pp. 197206.

General remarks on habits and distribution of blue jay, followed by an account of examination of 292 stomachs. The bulk of the food was found to be of vegetable origin, largely 
mast, the amount of fruit and cereals being small. In certain seasons of the year many inserts were eaten, few of them beneficial. But a very small percentage of the whole consisted of vertebrate remains, thus giving little support to the reports of danage done by eating snall birds, nor were birds' eggs caten to any extent. 'The relative proportions of the various foods varied remakably from season to season.

1897. Best, F. F. L. Some Common Birds in their Relation to Agriculture. U. S. Department of Agriculture, Firmer's Bulletin, No. 54.

A short popular discussion of the food habits of a number of birds of more or less importance to the farmer. Treats of the black and the yellow-billed cuckoos; the downy, golden-winged, hairy, red-shafted, and red-headed woodpeckers; the yellow-bellied woolpecker or sapsucker; the kingbird; the phobe; the blue jay; the bobolink or rice bird; the red-winged blackbird; the meadow lark or old field lark; the Baltimore oriole; the crow blackbird; the song, chipping, field, and tree sparrows; the snowbird; the rosebreasted grosbeak, the barn, eliff, and white-bellied swallows, and the martin; the cedar bird; the catbird; the brown thrasher; the house wren; the robin; and the bluebird. Most of these species are shown to be highly beneficial in their feeding habits.

1897. Bruxer, L. 'The Birds of Nebraska. Nebraska State Horticultural Society Report, 1896, pp. 98-178, 51 figures.

Notes on the distribution, food habits, etc., of birds of Nebraska, with list of forms found within the state. Corrected to April, 1896.

1897. Detcher, Wr. Report of A. O. U. Committee on Protection of North American Birds. The Auk, r. XIV, pp. $21-32$.

lieport of progress during the year.

1897. Grinvela, Joseph. Disgorgement among Song Birds. The Auk, v. XIT, p. 318.

Robins and cedar birds disgrorge seeds of pepper tree.

1897. Jones, Lrins. The Oberlin Grackle Ronst. The Wilson Bulletin, v. IX, O. S. Bulletin No. 15, July 30, 1897, рр. $39-56$. 
Iabits during conrtship and nesting; how the young are taken to the roost; eat fruit, then ripening corn; time of roosting; in the North the breeding season is beneficial to agriculture; the roosting season the reverse.

18!7. Jun), Srurester I). Methods in Economic Oruithology, with Special Reference to the Catbird. American Natmalist, Y. XXXI, Pp. :392-:i97.

proportions of foods ascertined by examination of stomach contents; preferences by field observations; sly birds canged and varions foods offered.

13!t. Kexpox, F. C. The English sparrow not always a Nuisance. American Naturalist, r. XXXI, p. 73.

Dr. Judle reports fondness for dandelion seeds; saw the sparrow catch and devour a cicada. His ability to catch insects on wing discussed.

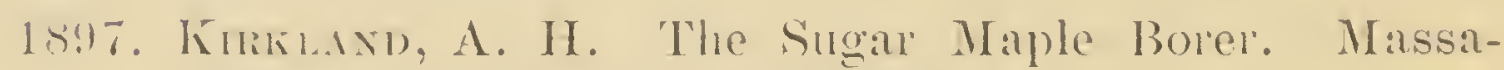
chusetts C'rop Report, June. 15!7, p. 32.

Presumptive evidence that hairy woodpecker, downy woodpecker, and flieker feed on larver of Plusionotus speciosus.

1897. Lucas, F. A. The Tongues of Birls. U. S. National MLuseum, Report for 1895, pp. 1001-1019.

Discusses the relation of the tongne to the hyoid, and the different forms of development of the two in the varions groups of birds.

1897. Owex. 1)arma. H. Notes on a Captive Hermit 'Thrush. The Auk, r. XIV, P). 1-8.

Account of feeding habits of hermit thrush; method of determining rate of digestion.

1897. P.unkr, 'T. S. Extermination of Noxious Animals by Bounties. U. S. Department of Agriculture, Tear Book. 1896, pp. 5.)-68.

History of bounty system in the United States and other comtries. Bounties on birds almost invariably pernicions.

1897. Proctor, 'Tuomas. Disgorgement among Song Birds. The Auk, i. XIV, p. 412. 
Wood thrushes and other true thrushes disgorge cherry pits; disgorgement also noticed in red-eyed vireo, inyrtle bird, and European robin.

1897. Reen, J. ITAmis. Notes on the American Barn Owl in Fastem Pennsylyania. The Auk, Y. XIV, pp. 374383.

Oecurrence, nesting liabits, feeding habits.

1897. WArrex, B. H. 'The Army Worm. Report Pennsylvania State College, 1896, pp. 164-220.

Reeord of studies of food of many birds during an army worm outbreak, showing that nearly all fed freely on the pests.

1898. Andus, Stwphex J. Swallow Investigations. The Wilson Bulletin, $\vee$ X, (. S. No. 20, May 30, 1898, pp. $42-43$.

They take enormous numbers of insects; nearly, if not quite, all taken on the wing. Barn swallows take enormous numbers of apple maggot flies.

1898. Batrer, L. H. The Birds and I. Cornell University, 'Teacher's' Leaflet, No. 10.

Popular diseussion of relations of birds to ehildren. Pictures of many bird houses.

1898. BeAI, F. E. I. Birds that Injure Grain. U. S. Department of Agriculture, Year Book, 1897, pp. 345-354.

After a short discussion of the damage done by birds to the wheat crop and the cause of inereased numbers of blackbirds, the more important noxious speeies are taken up in detail. The following are treated: Crow, erow blackbird, rerl-winged blackbird, yellow-headed blackbird, rusty grackle, eowbird, mourning dove, California valley quail, horned lark, and ecrtain imported pleasants.

1898. BEAL, F. E. L. The Food of Cuckoos. U. S. Division of Biological Surrey, Bnlletin 9, pp. 1-15.

General notes on North Ameriean cuckoos, followed by an account of the examination of 1.5.5 stomachs of botlı species. Food was found to consist almost exelusively of animal matter. Nearly 50 per eent. of the whole was eomposed of cater- 
pillars, of which, eontrary to the usual habits of birds, hairy species were in majority. The percentage of Orthoptera ranged from : s per cent. in Iray to 43 in July, nostly arboreal forms, and there were from 5 to $61-2$ per cent. of miscellaneous insects, beetles and bugs respectively. No particular support was found to the accusation that they are in the habit of sucking exgs of other birds.

1898. Bral, F. E. L. Birds and Farm Pests. Popular Seience Monthly, r. LII, P. 136.

Short but compreliensive article on birds relative to what insects they eat. Those which by his own methods are most easily obtained, ete.

1898. Butuer, Anos W. The Birds of Indiana. 'Twentysecond Annual Report State Geologist of Indiana. Pp. .) $1 \tilde{0}-118 \overline{6}$.

$A$ descriptive catalogrue of the birds that have been observed within the state, with an account of their habits. Much information as to food.

1898. Birds and 'Trees. Audubon Society of the State of Connecticut.

A four-page pamplilet containing selections suitable for bird day.

1898. Briswster. Wir. The Short-eared Owls of Muskeget Island. 'The Auk, r. XV, pp. 211-213.

"Bird protectors would do well to study more closely the balance of nature." Notes on Owls of Muskeget Island.

1898. Crum, Wu. Ekrert. Woodpeckers and Their Ways. Popular Science Monthly, v. LIII, p. 339.

Eating aphides in fall.

1898. Dutcher, Wn. (Chairman). Report of the A. O. U. Conmittee on Protection of North American Birds. The Auk, V. XV, pp. 81-114.

An extended discussion showing work in the different states, witl general recommendations.

1898. Honsady, W' T'. 'The Destruction of Our Birds and Mammals. Second Anmual Report of the New York Zoölogical Society, pp. 77-126. 
A eirenlar letter of inquiry was sent to persons in varions states and territories, and the results here given. 'The subjects for investigation were the per eent. of decease of birds in varions localities, and the canses for such decrease. The results are given in detail.

189. S. Helps to Bird Study. Massachusetts Aunubon Society, 1898.

A pamplilet of thirty-two pages giving selections in prose and verse helpful for bird day programmes.

1898. Junn, Sruvester I). The Food of Shrikes. U. S. Division of Biological Survey, Bulletin ?, pp. 15-26.

General notes on North American shrikes, followed by an account of the examination of 155 stomachs of both species. So far as could be determined from the stomachs of 67 butcher birds the food closely resembled the sparrow hawk. About 26 per cent. of the food consisted of mice, 34 per cent. of small birds, including many English sparrows, consisting almost wholly of seed-eating species, and the remainder of insects, mostly grasshoppers. The food of the loggerhead differs in the much smaller percentage of mice and birds, about 24 per cent. The insects eaten consist largely of Orthoptera, and in the spring of beetles, many of them predaceous species. Both the butcher bird and loggerhead eat, to some extent, caterpillars.

1898. Kenticote, I). S. Feeding Habits of Winter Birds of Interior Ohio. Journal Columbus Horticultural Society, v. XIII, pp. $45-51$.

A brief discussion of feeding habits with list of winter residents.

1898. Lazensy, Wm. R. Preserve the Birds. Journal Columbus Horticultural Society, v. XIII, pp. 44, 45.

A brief discussion of benefits of birds and methods of protecting them.

1898. Merriam, Florence A. Birds of Village and Field. A bird book for beginners. Boston: Houghton, Mifllin \& Co.. 1898.

A book of 406 pages with 220 illustrations, with considerable attention to the economic relations of the birds discussed.

1898. Nash, Charles W. 'The Birds of Ontario in Relation to Agriculture. 'Coronto: Department of Agriculture, 1898, p. 64. 
A general discussion of the economic status of the common birds of Ontario, with figures of many species.

1898. Saxderson, E. Dwhint. The Fconomic Value of the White-bellied Nuthatch and Black-capped Chickadee. 'The Auk, r. XY, pl). 14t-1és.

Record of food of 2:) muthatches in winter and 11 in early spring, and of 19 clickadees in winter and 9 in spring.

1rigs. Wred, Crablixce Moorks. Onl Largest Standing Aluy, the Birds. (iranite Monthly, r. XXY, pl).325$3: 31$.

Discussion of regulative action of birks.

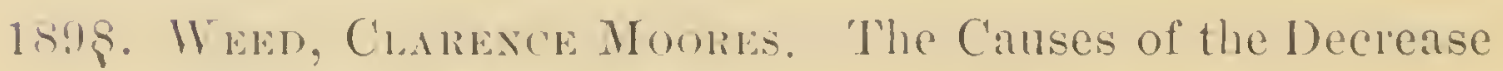
of Birds. Glanite Monthly, r. XXY, 1). 211-215.

An illustrated discussion of the subject.

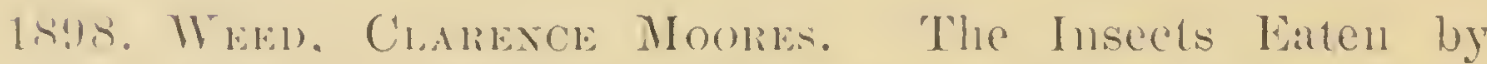
Bilds. Agricultural Education, v. 1, Pr). 1-7, 51-53.

Illustrated discussion of the insects most eommonly fed upon by birds.

1898. Wren, Chalback MoOris. The Feeding Habits of the Chipping Sparrow. New Hampshire College Agricultural Experiment Station, Bulletin 5i, July, 1898.

An ilinstrated aceount of a day's work by a pair of chipping sparrows feeding three young. Nearly 200 visits to the nest were marle.

1598. Wratam-ox, E. B. The Economic Importance of Some Common Birels. Iomrnal of Colmmbus Horticultulial Society, r. XIII, P). 3:i-44.

'louclies upon the economic importance of many species of North Imerican birds, with notes on feeding habits of some of them in Ohio.

1899. LEAl, F. E. I. Feononnic Relations of Birds and Their Foods. Proceedings 2 fth Annual Meeting New Jersey State Horticultural Society, 1899.

A general discussion of the subject. 


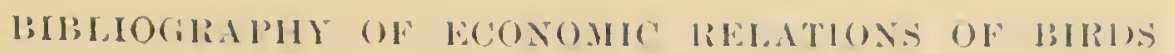

1899. Chapmat, Fraxk M. Bird life. New York: 1). Appleton \& Co., 1899 .

'This adnilable book eontains a brief account in Chapter' I of the relation of birds to minn.

1899. Chapuax, Fiank M. The Passing of the Teph. Bird Lole, r. I, p). $205-206$.

Use of terns for millinery purposes leading to their extermination.

1899. Chask, Victol P. A Blood-thirsty Bhe Jay. The Wilsou Bulletin, r. XI, O. S. No. 27, July 3(), 1899, pp. $55-56$.

Eats cherries; killed a newly fledged English sparrow.

1899. Grant, Arre MI. Birds. Report Rhode Island Board of Agriculture, 1899 .

Discussion of economic value of birds.

1899. Hodge, C. F., and Bate, Helex A. Our Commou Birds. Suggestions for the Study of their Life and Work. Wrorcester, November, 1899.

Record of work in bird study in schools of Worcester, Mass.

1899. Ju1n, Srivester D. Birds as Weed Destroyers. U.S. Department of Agriculture, Year Book, 1898, pp. 221$2: 32$.

A general discussion of the kinds of seeds eaten by birds and the species that eat them.

1899. Lavil;, 1). Our Native Birds; How to Protect Them and Attract 'Then to Our Homes. New York: The Macmillan Co.o., 1899.

A small volume of 162 pages with 10 illustrations.

1899. Palmer, 'T. S. The I)anger of Introdneing Noxious Animals and Birds. U.S. Department of Agriculture, Year Book, 1898, pl. $87-110$.

Introduction, means of dispersal, domesticated species may become noxious, sources of danger from noxiouśspecies, 
rats and mice, rabbits, the mongoose, ferrets, stoats, weasels, flying foxes or fruit bats, the English sparrow, the starling, the mina. the kohlmeise or great titmouse, the skylark, the green linnet, and the black thrush; need of legislation; summary.

1899. Oscomb, Fuetches. The So-called Sparrow War in Boston. Bird Lore, v. 1. pp. 137-138.

Accomt of the campaign against English sparrows in Boston in the spring of 1898 .

1s99. (). .. I. Martins Kill the Caterpillars. The Wilson Bulletin, r. XI, (). S. No. 27, July :i(), 1s!9, pp. 60, 61.

Built a martin house in orehard; this was soon filled; liept caterpillars and moths from orchard.

1rige. Sortes, Ciromane G. Birds and Caterpillars. Birl L,ole, V. I, p. 166.

Notes on birds attacking forest tent caterpillar's (Clisiocempa aisstria) in Vermont.

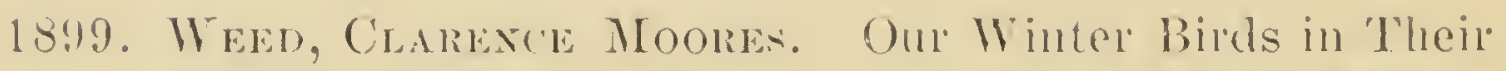
Food Relations. The (ximite Monthly, r. XXYT, 1). 7 \% -8.2 .

Food of pine grosbeak, jurple finch, junco, chickadee, nuthatches, brown creeper, hairy and downy woodpeckers, and ruffed grouse.

1900. Bankr, Versox. Where the Grebe Skins Come From. Bircl Lore, r. II, p. 3.4.

Destruction of grebes in Califormia and Oregon to supply demands of fashion.

1900. Brkss, Fraxk L. A Monograph of the Flicker. The Wilson Bulletin, r. XII, O. S. No. 31, April, 1900, pp. $3-8 \cdot 2$.

An eighty-two page monorraph bringing together what is known of the flicker.

Hard to find birds with fewer harmful qualities than downy and hairy woodpeckers and flicker. Eats ants, coleoptera and other insects.

1900. Chapmax, Fraxk M. Bird Studies with a Camera. New Iork: I). Appleton \& Co., 1900. 
This well known book eontains mueh information regarding conomic relations of birds.

1900. Cuapuas, Frank Mr. Bird Slanghter in Delaware. Bird Lore, v. 11, p. 60.

Note on order for 20,000 bird skins placed in Milford, Delaware.

1900. Chapux, Fraxk M. A Note on the Economic Value of Crulls. Bird Lore, v. II, Pl. 10-11.

Talue of gulls in feeding on garbage in New York harbor.

1900. Cumrris, Georar K. The Egret Hunters of Venezuela. Bild Lole, V. II, pp. 50-51.

Aceount of eolleetion of plumes by natives of Venezuela.

1900. Dibble, Eoward B. 'Two Notes by a Young Observer' Bird Iole, r. II, p. 117.

Observations on robbing of birds' nests by blue jays, and on feeding of young by horned larks.

1900. Dutcher, Wr. The Bird Protection Fund. Bird Lore, r. II, Pp. 60, 90.

Fund of $\$+77$ raised for proteetion of gulls and terus. Arrangements being made for wardens to enforee laws.

1900. (Enitor.) Sparrows Eat Grapes. Gardening, v. IX, p. 29.

Injury to grapes by English sparrows.

1900. Hutchiss, Jonx. 'The House Wren as a Depredator. bird Lore, v. II, pp. 89-90.

Wrens picrec eggs of ehipping sparrows and throw them out of nest, also persecute other birds.

1900. Lmmoxs, Istremla McC. Notes on the Food of the Chickadee and the Screech Owl. Bird Lore, r. II, p. 59.

Chickadces observed taking "tiny black insects" (probably aphid eggs) from willow. Sercech owls' stomaelıs full of harvest flics "in the pupa form in which they leave the eartlı." 
1900. Palmek, 'T. S. Protest Against the Collection of Plume Birds through Postmasters. Bird Lore, r. II, 1. 66 .

Account of action of postmaster-general in warning postmasters against illegal killing of birds.

1900. Prakger, Whrlan F. Birds in Horticulture. 'Thansactions Illinois State Horticultural Society, 1899. Review in Bird Lore, r. 11, p. 61.

A paper discussing the economic values of birds.

1900. Rooshert, 'Theonore. A Tetter' from Govenol Rooserelt. Bird Lore, v. II, p. 98.

Endorsement of work of Audubon society.

1901. Cran. W. E. Food of the Downy Woodpecker. Bird Lore, r. II, p. 142.

Feedingr on larre in mullen seed cases.

1901. Dearborx, Nen, and Weled, Crablixes M. 'The Vegetable Food of Birds. Granite Monthly, r. XXXIII, p). $277-286$.

1901. Dliarbolix, Ned, and Whed, Clablexce M. Birds in theil Economic Relations. Granite Monthly. $\vee$. XXXI, pp. 158-167, 276-285.

Discussion of various pliases of the subject.

1901. Eokton, Faxie Harmy. The Bird Book. Boston: 1). C. Heath \& Co., 1901.

In this unique book there is much information of economic value.

1901. Eckstorn, Faxile Hanm. Visible Results. Bird Lore, r. III, p. 184.

Reappearance of terns along the Maine coast.

1901. (Evitor.) 'The Sparrow Again. American Gardening, v. XXII, pp) 759-760.

Usefulness of English sparrows in cities. 


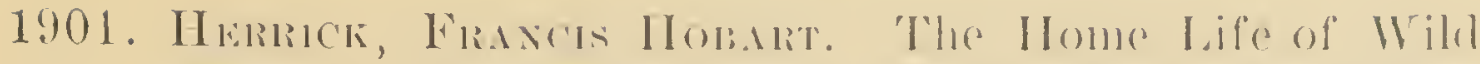
Bircis: a New Method of the sturly and l'hotogiathy of Birds. New York: (x. P'. Putnants's sons, 1901.

A beautiful book of 148 large pages giving methouls of photographing birds at elose range, and results of study of nesting habits. Notes on food of nestlings of several species.

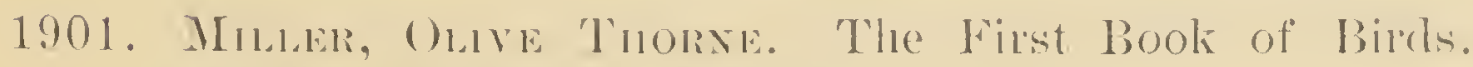
Boston: Iloughton, Millin \& Co, 1901.

In this excellent book for children there is considerable discussion of economic relations, one division of the book being devoted to the relations of birds to man.

1901. Mnler, Ohre 'Tholixk. The Second Book of Birds: Bird Families. Boston: IIonghton, Mifllin \& Co., 1901 .

An illustrated account of the families of North American birds, with numerous references to feeding habits.

1901. Newkrk Garretr. For Our Enconragement. Birrl Lore, v. III, 1p. 18.3-184.

Increase of birds in Missouri because of bird protection.

1901. Pamer, T. S. Some Fundamental Principles of IBirl Protection. Bird Lore, v. III, Pp. 7!-81.

An armirable discnssion of principles on which laws are basel.

1901. Peabody, P. B. Sam-Wrhet IIomes. Bird Lore, v. III, PP. $55-58$.

Account of nests of saw-whet owls in flicker holes. Evidences of mice and small birds as food.

1901. Surth, Roblert Wismoror. l'ood and Giarel. The Wilson Bulletiu No. :4, v. XIII, (). S. March 30,1901 , p). 16,17 .

Song sparrow hats much gravel in stomach; robin more dirt than gravel; seed-eating birds require it for grinding. 





\section{Date Due}

MAR 111953 


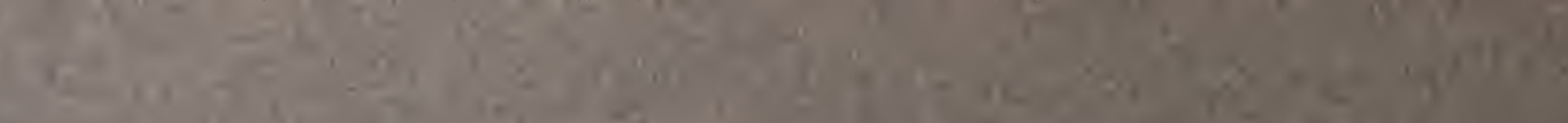
$6-13 \cdot 2 y^{\prime}$

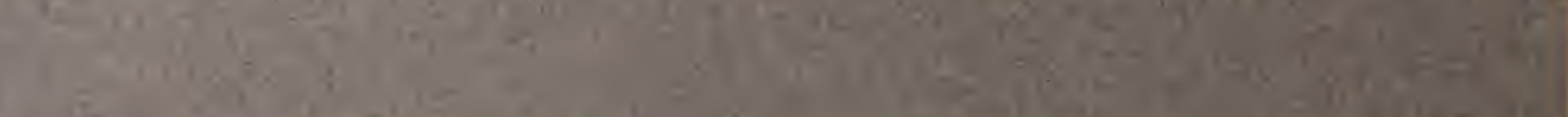

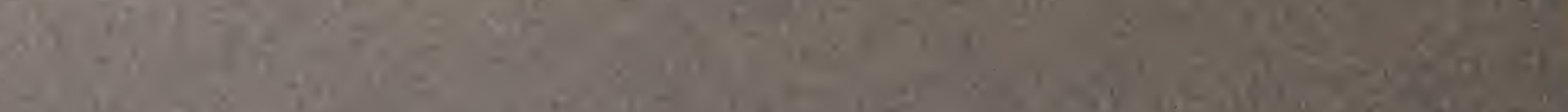

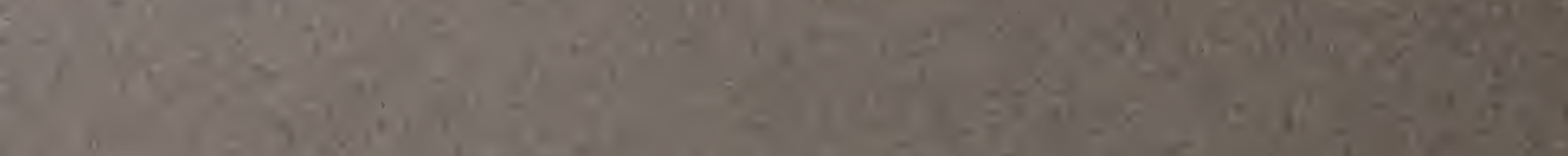

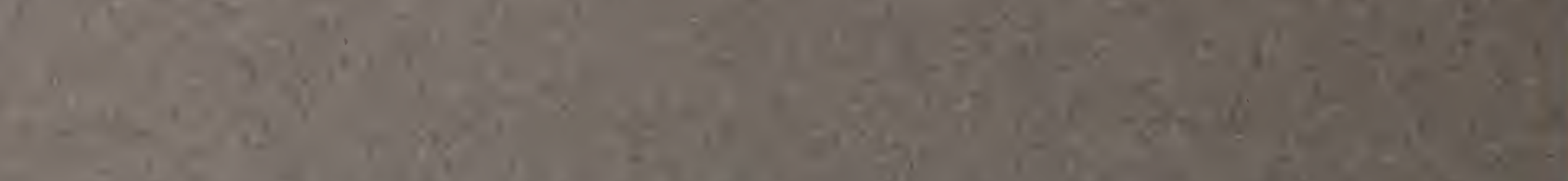
8.

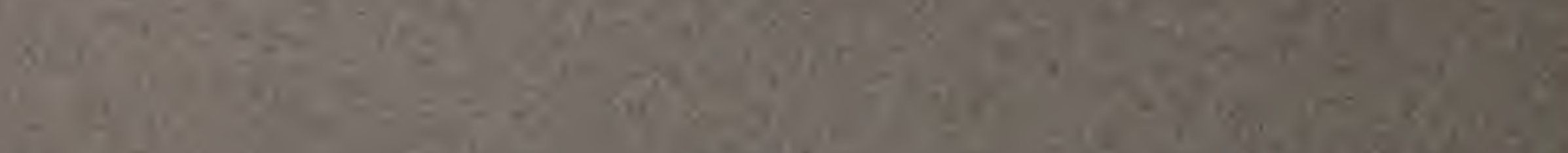

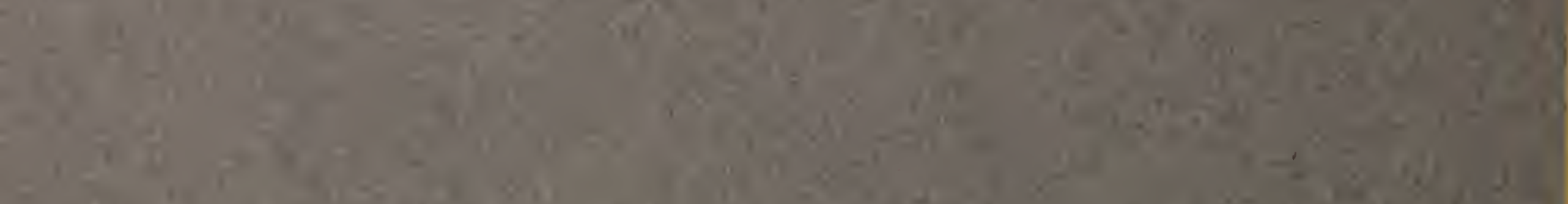

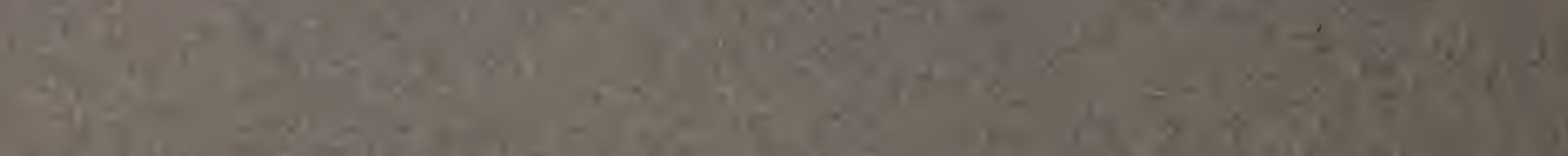

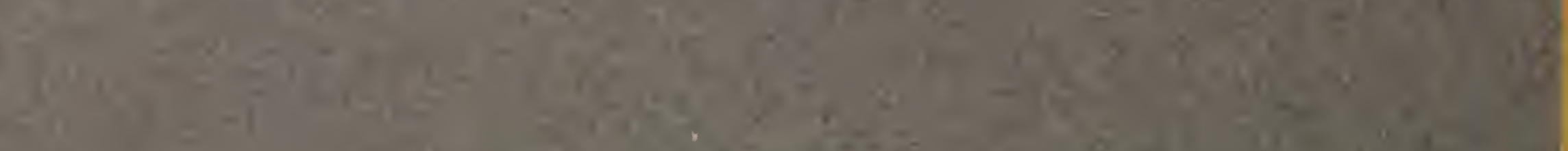

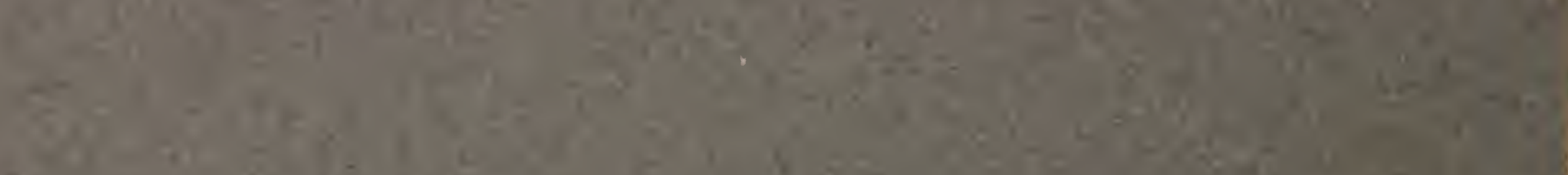

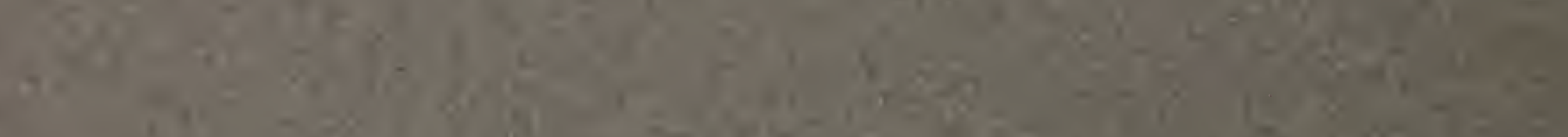

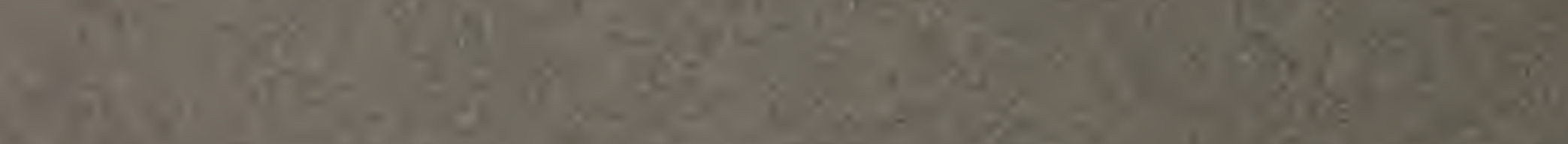

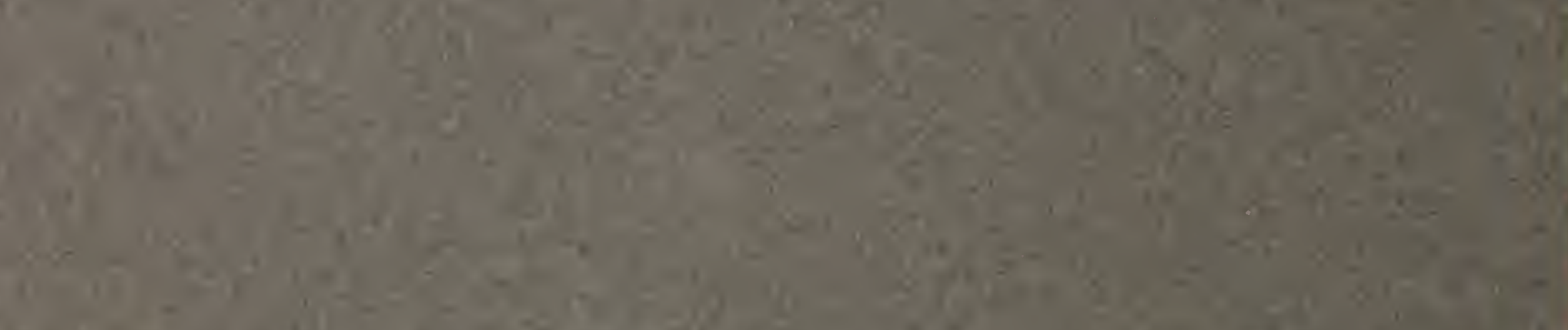

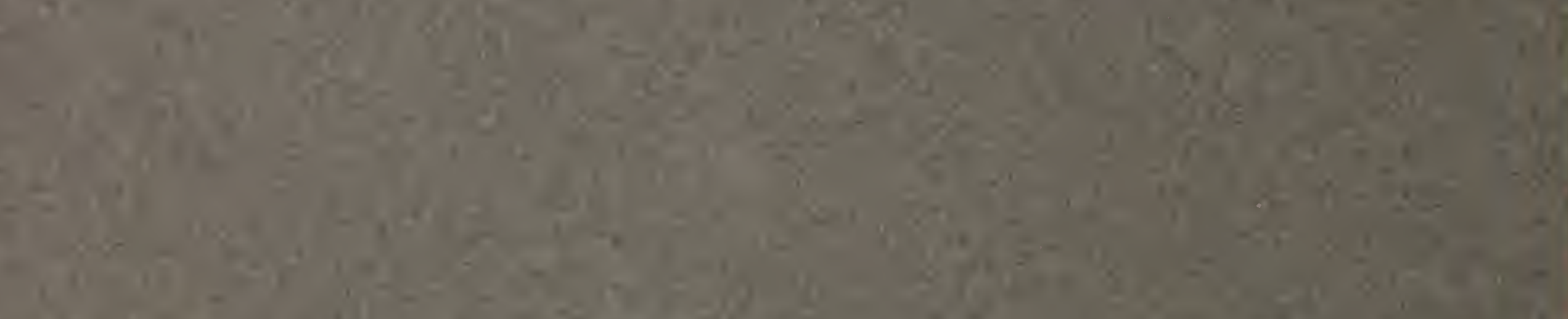

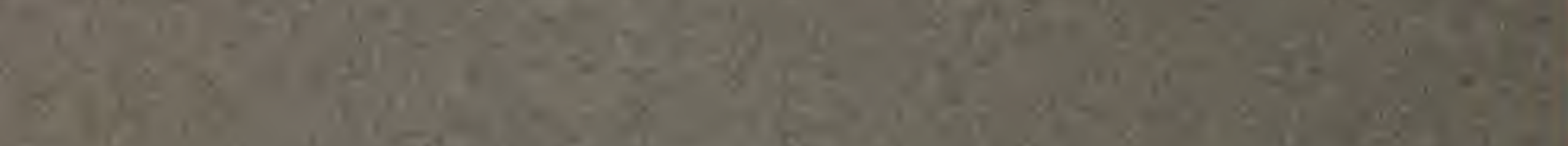

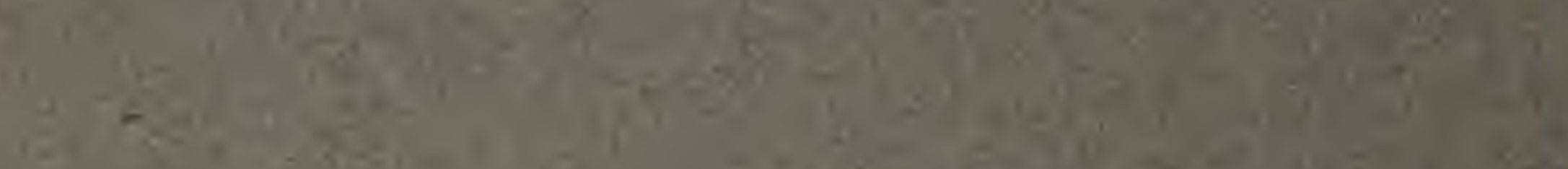

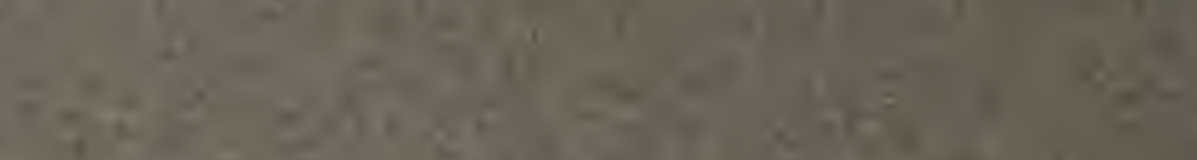

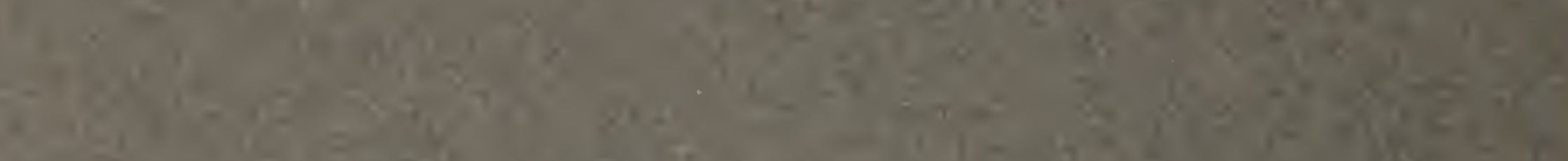

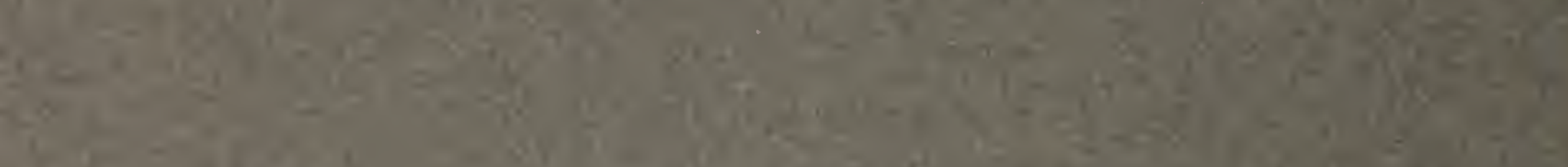

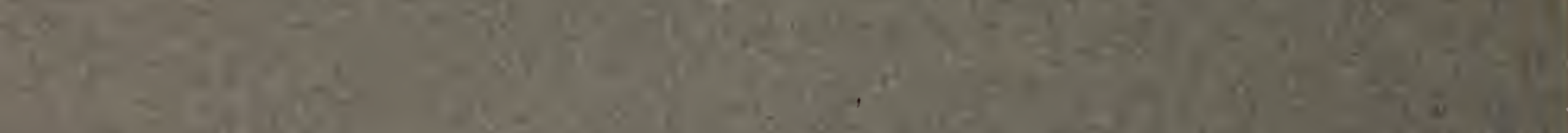

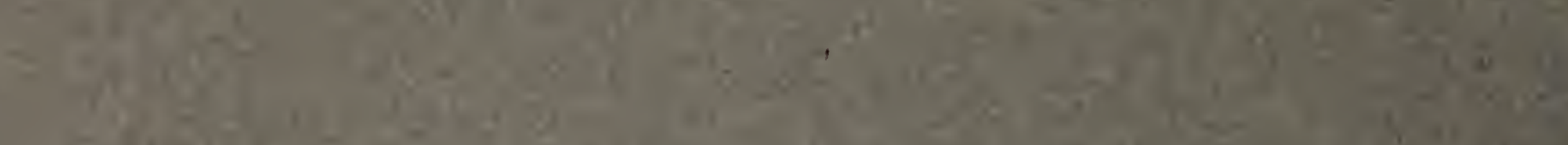

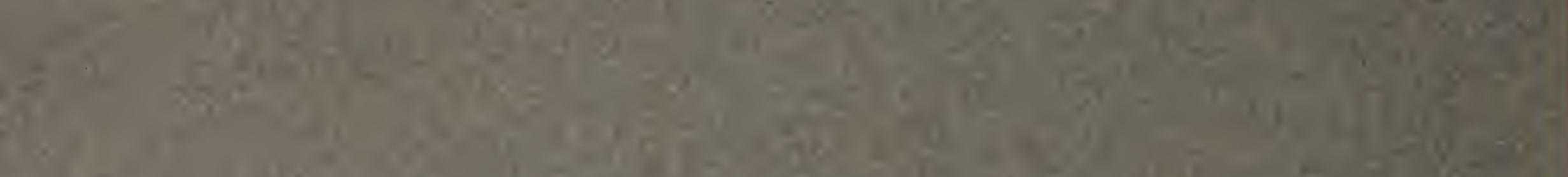

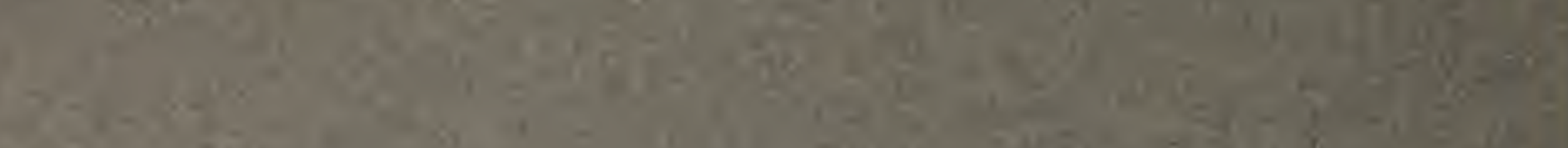
W.

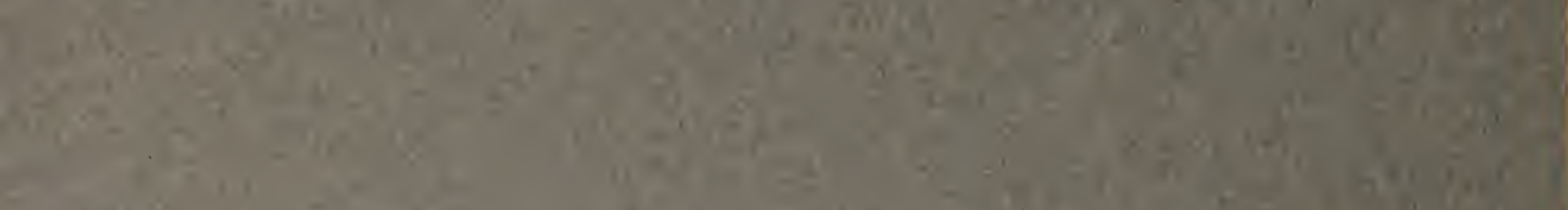

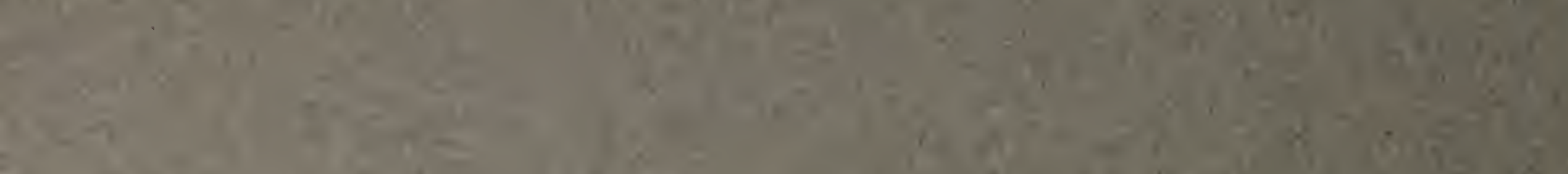
:

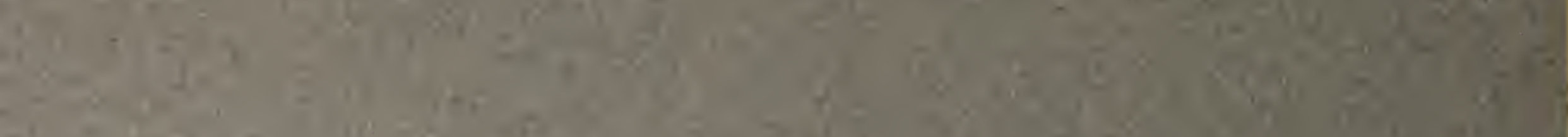

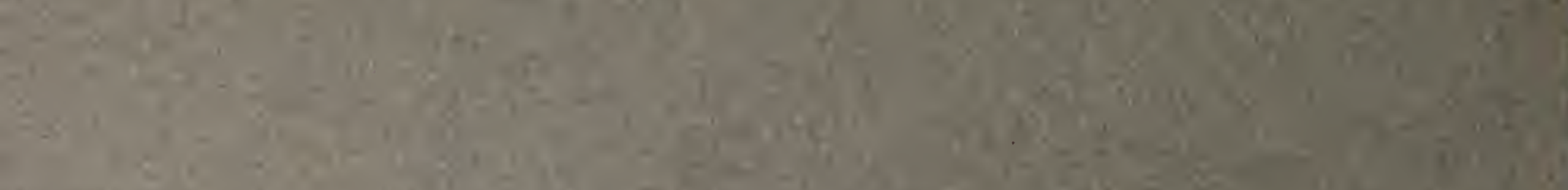

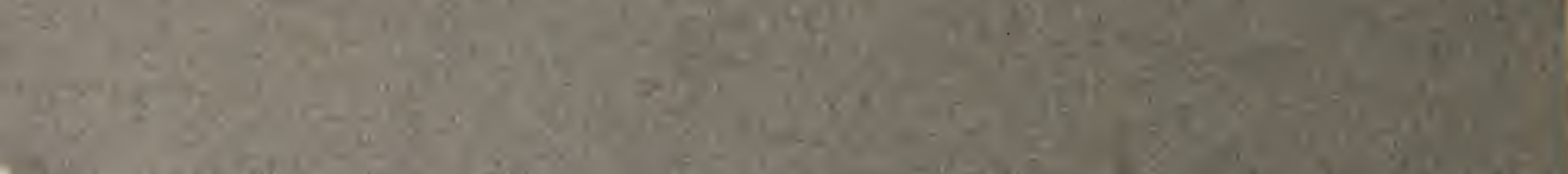

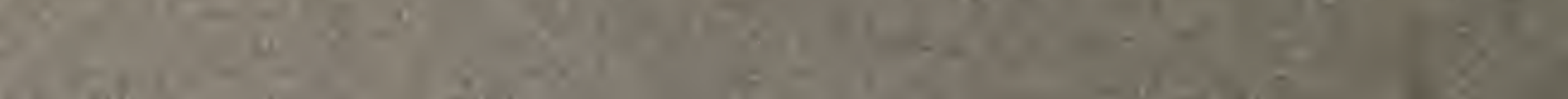

